\title{
A Review on Energy Piles Design, Evaluation, and Optimization
}

\author{
Zahraa MOHAMAD $^{(1)(2)}$, Farouk FARDOUN ${ }^{(1)(3)}$ Fekri MEFTAH $^{(2)(4)}$
}

(1) Doctoral School of Science and Technology, Modeling Center, Lebanese University, Hadath, Lebanon

(2) Civil engineering and mechanical engineering laboratory (LGCGM), INSA Rennes, Rennes, France

(3) Faculty of Technology, Department GIM, Lebanese University, Saida, Lebanon

${ }^{(4)}$ Civil Engineering And Urban Planning Department (GCU), INSA Rennes, Rennes, France

\begin{abstract}
Integrating heat exchanger pipes with structural foundations in one system has created a new renewable solution for buildings' thermal loads. However, the interaction between thermal and geotechnical loads makes their design more complex and challenging. This review-study represents the current state of knowledge about the thermal and thermo-mechanical behaviors of energy piles. It also investigates the key parameters that affect their design concerning the piles' dimensions, the arrangement of pipes, concrete admixture, and fluid characteristics. It is found that the thermal efficiency improves significantly by increasing the number of pipes inside the piles and by adding thermally conductive materials to the concrete within acceptable limits. Besides, this paper reviews most of the studies conducted on optimizing vertical ground heat exchangers coupled with heat pumps. Objective functions, decision variables, design constraints, and optimization methods are specified and listed. It is concluded that a multi-objective optimization is highly recommended to enhance the dual performance of an energy pile system coupled with a heat pump using the $4 \mathrm{E}$ evaluation criteria (energy, exergy, economy, and environment) while ensuring the safety of the foundation under thermal cyclic loads.
\end{abstract}

Keywords: energy piles, thermo-mechanical behavior, design parameters, 4E-G evaluation criteria, optimization. 


\section{Contents}

1. Introduction

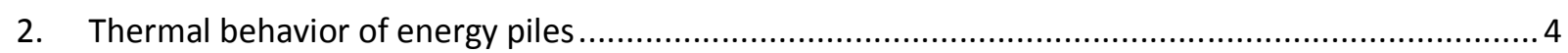

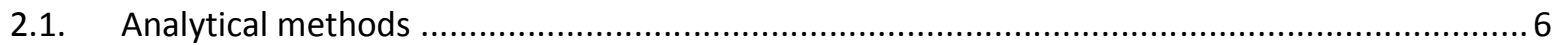

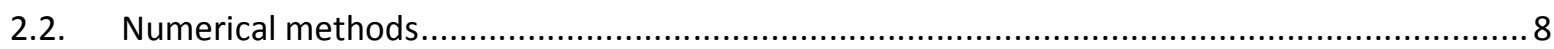

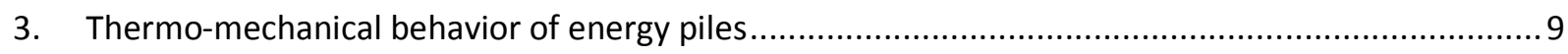

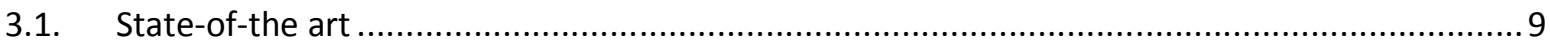

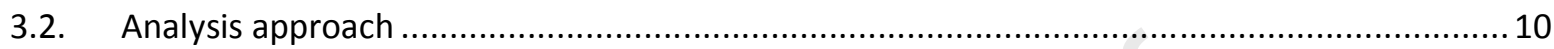

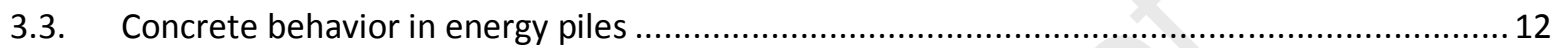

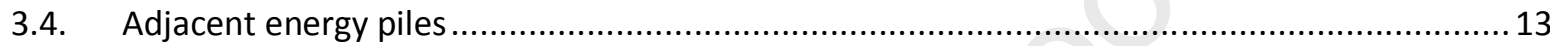

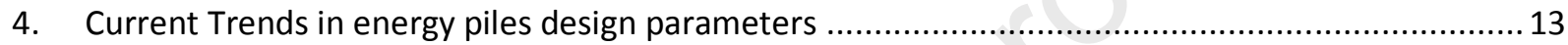

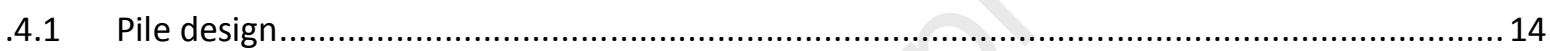

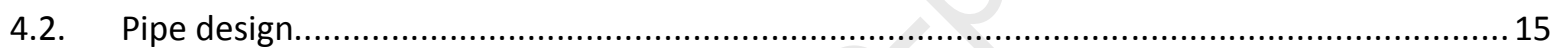

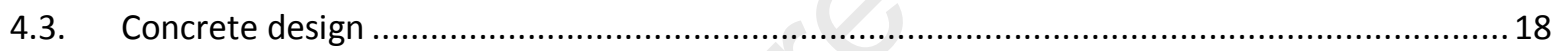

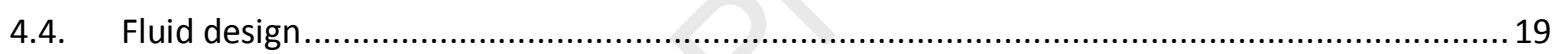

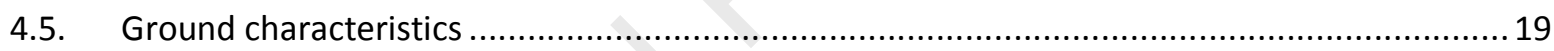

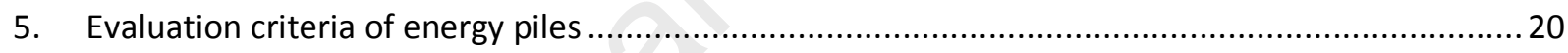

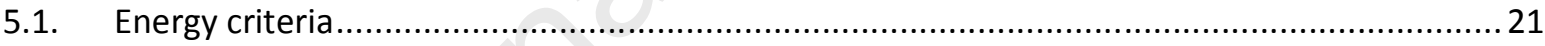

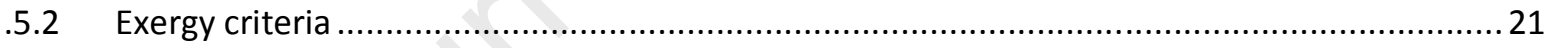

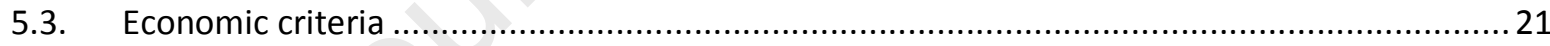

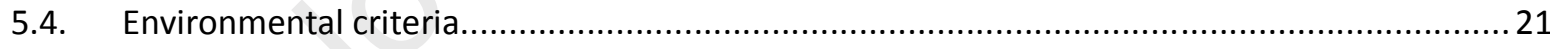

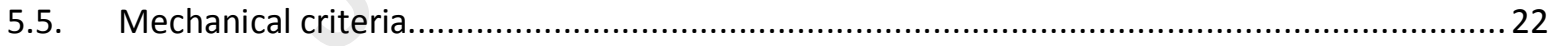

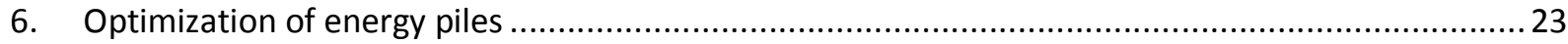

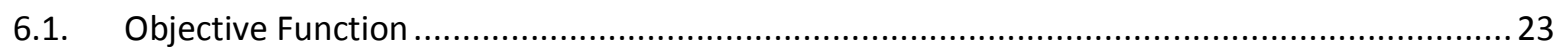

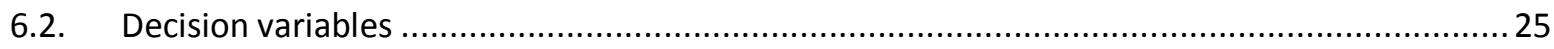

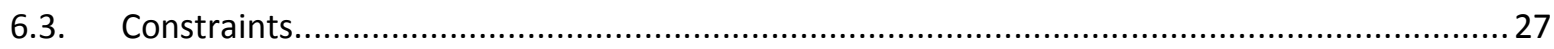

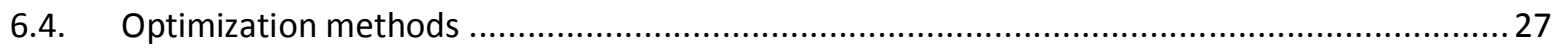

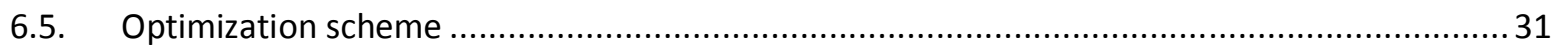

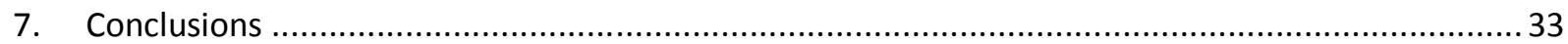




\section{Table of Abbreviation}

\begin{tabular}{|c|c|c|c|}
\hline Nomenclature & & Symbol & \\
\hline BHE & Borehole heat exchanger & $\mathrm{s}_{\mathrm{p}}$ & Pipes spacing \\
\hline CFD & Computational fluid dynamics & $\lambda_{\mathrm{g}}$ & Thermal conductivity of grouting material \\
\hline COP & Coefficient of performance & $\lambda_{\mathrm{p}}$ & Thermal conductivity of pipe material \\
\hline DOF & Degree of freedom & $\mathrm{D}_{\mathrm{b}}$ & Borehole diameter \\
\hline EGN & Entropy generation number & $\mathrm{N}_{\mathrm{b}}$ & Number of boreholes \\
\hline EP & Energy pile & $\mathrm{N}_{\mathrm{p}}$ & Number of pipes \\
\hline FDM & Finite difference model & $\mathrm{R}_{\mathrm{e}}$ & Reynolds number \\
\hline FEM & Finite element model & $\mathrm{T}_{\mathrm{in}}$ & Inlet fluid temperature \\
\hline FLSM & Finite line source model & $\mathrm{T}_{\text {out }}$ & The outlet fluid temperature \\
\hline FRSM & Finite ring source model & $\mathrm{m}_{\mathrm{f}}$ & Mass flow rate \\
\hline FSSM & Finite spiral source model & $r_{b}$ & Borehole radius \\
\hline FVM & Finite volume model & $\lambda_{s}$ & Thermal conductivity of the soil \\
\hline GA & Genetic algorithm & $r_{p}$ & Pipe radius \\
\hline GHE & Ground heat exchanger & $s_{b}$ & Borehole spacing \\
\hline GSHP & Ground source heat pump system & $\mathrm{s}_{\mathrm{p}}$ & Pipes spacing \\
\hline $\mathrm{HJ}$ & Hooke-Jeeves pattern search algorithm & $\Delta \mathrm{T}$ & Temperature change \\
\hline HTF & Heat transfer fluid & $E$ & Youngs modulus \\
\hline ICSM & Infinite cylinder source model & $\alpha$ & Thermal expansion coefficient \\
\hline ILSM & Infinite line source model & $\sigma_{t h}$ & Thermal stress \\
\hline IRSM & Infinite ring source model & $\varepsilon_{t h}$ & Thermal strain \\
\hline ISSM & Infinite spiral source model & $\omega_{z}$ & Vertical displacement \\
\hline LCC & Life cycle cost & & \\
\hline MINLP & Mixed-integer Non-linear programming & & \\
\hline NM & The Nelder-Mead method & & \\
\hline NPV & Net present value & & \\
\hline PCM & Phase change material & & \\
\hline SCSM & Composite cylinder source model & & \\
\hline TAC & Total annual cost & & \\
\hline
\end{tabular}

\section{Introduction}

Energy consumption of buildings has become a relevant international issue, and various design strategies have been developed to enhance energy saving in many countries. Today, Buildings' responsibility for approximately $40 \%$ of total energy consumption and over $30 \%$ of greenhouse gas emissions [1] has shifted global interest toward the so-called "Nearly zero energy buildings" (NZEB). The design of an NZEB has the purpose of constructing buildings with less energy consumption and low carbon emission. The development of energy geo-structures contributes to this goal as applying shallow geothermal energy in geo-structures for space cooling and heating of buildings. This environmentally friendly technology can be applied to all types of soil-embedded structures such as the diaphragm walls, tunnels, shallow foundations, and piles [2]. In the past years, an increasing number of energy geostructure projects have been implemented in many countries where they have achieved a cumulative share of carbon dioxide savings worldwide (Figure 1). The Laizer tunnel in Vienna (Austria), the Keble College in Oxford (UK), the Dock Midfield terminal at Zurich airport in Switzerland, and the Wuxi Guolian Tower in China are some applications for various types of energy geo-structures in the 
world $[2,3]$. Among all these types, the energy pile remains the most common application for the ground heat exchange process. It takes advantage of the relative stability of underground temperature below a depth of $15 \mathrm{~m}$ to $50 \mathrm{~m}$ to extract or reject heat from/to the ground. The heat transfer is carried out in an energy pile through ground heat exchanger (GHE) pipes installed along their reinforcement cage, where the heat transfer fluid (HTF) circulates and exchanges heat with the surrounding. Despite the rapid spread of this technology, especially in the UK and Austria, energy piles' installation still faces considerable challenges due to the interaction between thermal and geotechnical design [4]. Many studies have been conducted or are ongoing to examine the performance of energy piles. Most of them are based on energy performance, but many recent studies have also been published to understand their thermo-mechanical behavior through in situ experiments, laboratory tests, and numerical analyses. Simultaneously, some authors have reviewed research studies in this field [5-15]. However, they do not address the optimization aspects of energy piles under thermo-mechanical interactions. This paper presents a comprehensive review of all energy piles' features: evaluation, design, and optimization. It interprets the complex performance of energy piles, expands knowledge on their evaluation criteria and design parameters, and provides design recommendations. It also attempts to develop an approach to optimize energy piles' design, considering thermal, economic, environmental, and mechanical perspectives.
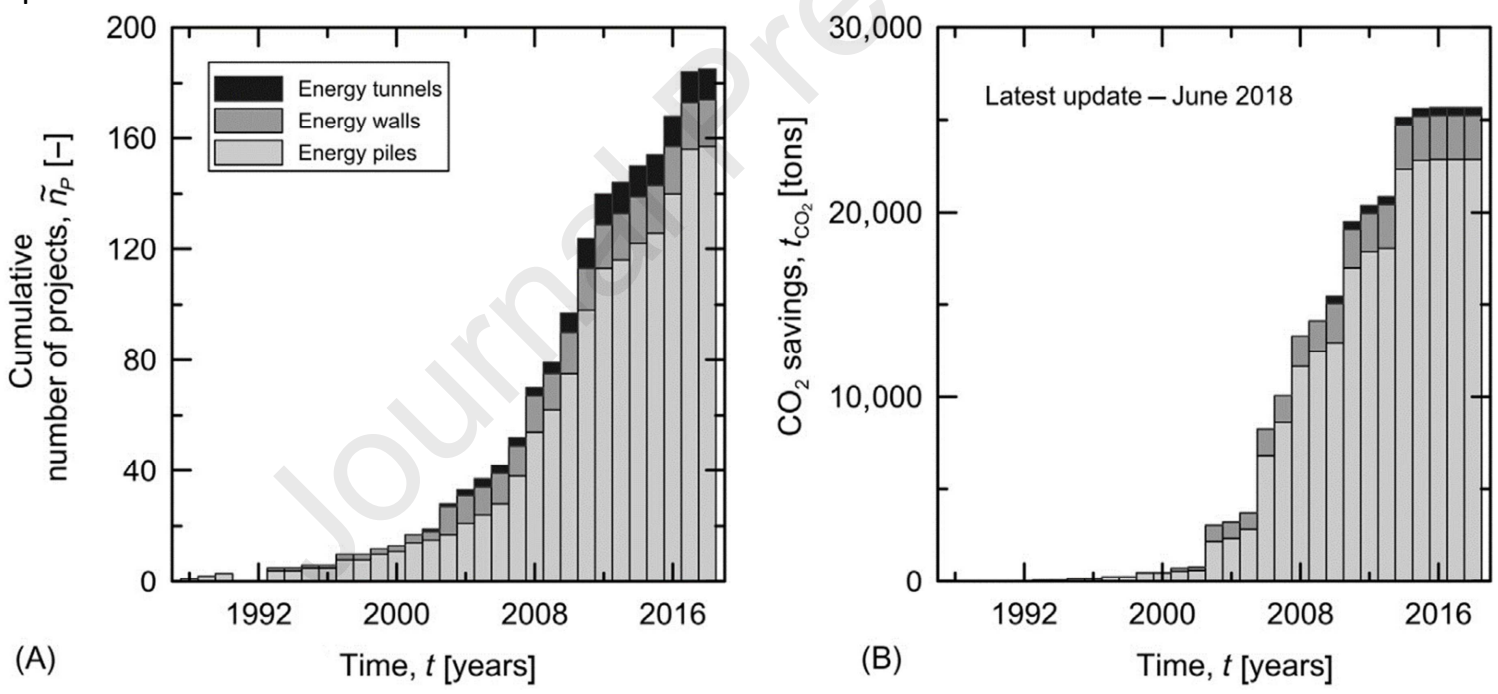

Figure 1. Cumulative number of (A) energy geostructure projects worldwide and (B) carbon dioxide savings worldwide [16].

\section{Thermal behavior of energy piles}

Understanding the heat transfer across energy piles is the first step in designing these systems. The thermal process goes in an energy pile, as in a borehole heat exchanger, in different stages: heat transfer through the ground, conduction through pile concrete and heat exchanger pipes, and convection in the fluid and at the interface with the inner surface of the pipes (Figure 2). Analytical and numerical studies have been conducted to analyze these systems' thermal performance (Table 1). 


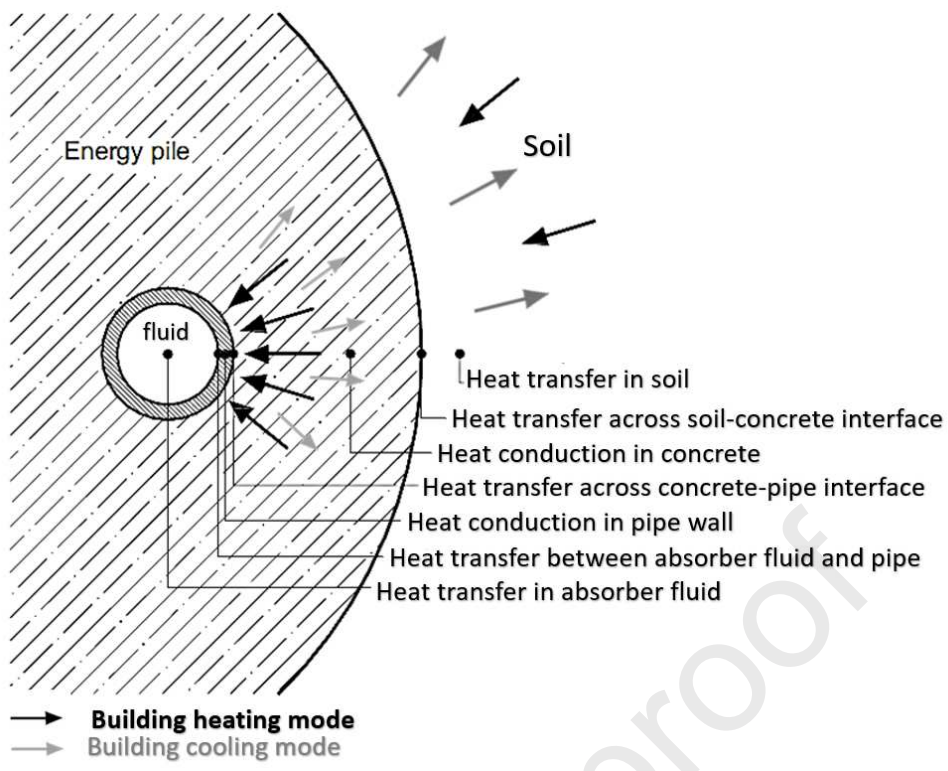

Figure 2. Heat transfer stages in an energy pile

Table 1. Recent studies on the thermal behavior of energy piles.

\begin{tabular}{|c|c|c|c|c|c|c|c|}
\hline Reference & $\begin{array}{l}\text { Pipe } \\
\text { configuration }\end{array}$ & Pile size & $\begin{array}{l}\text { Method } \\
\text { and/or } \\
\text { software }\end{array}$ & $\begin{array}{c}\text { Nume } \\
\text { rical }\end{array}$ & $\begin{array}{l}\text { Analy } \\
\text { tical }\end{array}$ & $\begin{array}{l}\text { Experi } \\
\text { mental }\end{array}$ & Results \\
\hline $\begin{array}{l}\text { [17] } \\
\text { Park et al. }\end{array}$ & 5 U-tubes & $\mathrm{D}=1.5 \mathrm{~m}$ & $\begin{array}{l}\text { Engineering } \\
\text { chart }\end{array}$ & $\checkmark$ & $\checkmark$ & & $\begin{array}{l}\text { The chart presents a good estimation of the } \\
\text { rate of heat transfer compared to numerical } \\
\text { analysis. }\end{array}$ \\
\hline $\begin{array}{l}{[18]} \\
\text { Lei et al. }\end{array}$ & Spiral coil & 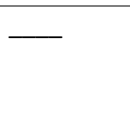 & $\begin{array}{l}\text { hybrid } \\
\text { analytical } \\
\text { model }\end{array}$ & & $\checkmark$ & & $\begin{array}{l}\text { Results with homogeneity assumption present } \\
\text { acceptable errors. }\end{array}$ \\
\hline $\begin{array}{l}\text { [19] } \\
\text { Cui and } \\
\text { Zhu }\end{array}$ & U-tube & $\begin{array}{l}\mathrm{D}=0.3 \mathrm{~m} \\
\mathrm{~L}=10 \mathrm{~m}\end{array}$ & 3D FVM & $\checkmark$ & & & $\begin{array}{l}\text { Reduction in soil temperature after a year of } \\
\text { operation. } \\
\text { Rapid soil temperature recovery with reduced } \\
\text { volumetric heat capacity and high thermal } \\
\text { conductivity of the soil. }\end{array}$ \\
\hline $\begin{array}{l}\text { [20] } \\
\text { Rui et al. }\end{array}$ & U-tube & $\begin{array}{l}D=2.5 \mathrm{~m} \\
L=28 \mathrm{~m}\end{array}$ & 1D FEM & $\checkmark$ & & & $\begin{array}{l}\text { Steady-state is attained after } 12-13 \text { years of } \\
\text { operation. } \\
50 \% \text { reduction in the energy consumption for } \\
\text { GSHP after } 30 \text { years of service. }\end{array}$ \\
\hline $\begin{array}{l}\text { [21] } \\
\text { Cui and } \\
\text { Zhu }\end{array}$ & U-tube & $\begin{array}{l}\mathrm{D}=0.3 \mathrm{~m} \\
\mathrm{~L}=10 \mathrm{~m}\end{array}$ & $\begin{array}{l}\text { 3D FVM } \\
\text { CFD analysis }\end{array}$ & $\checkmark$ & & & $\begin{array}{l}\text { The values of the CFD model deviate by } 12 \% \\
\text { from the experimental results. } \\
\text { The intermittent operation leads to higher COP } \\
\text { values than continuous operations. }\end{array}$ \\
\hline $\begin{array}{l}\text { [22] } \\
\text { Ghasemi- } \\
\text { Fare and } \\
\text { Basu }\end{array}$ & U-tube & $\begin{array}{l}\mathrm{D}=110 \mathrm{~mm} \\
\mathrm{~L}=1.22 \mathrm{~m}\end{array}$ & $\begin{array}{l}\text { Thermal } \\
\text { loading tests } \\
\text { FDM }\end{array}$ & $\checkmark$ & & $\checkmark$ & $\begin{array}{l}\text { Results show a higher pile-soil temperature } \\
\text { gradient in saturated soil. } \\
\text { The thermal conductivity at the wall of the } \\
\text { pile }=50 \% \text { and } 63 \% \text { of the thermal conductivity } \\
\text { of soil measured in dry and saturated } \\
\text { conditions. }\end{array}$ \\
\hline $\begin{array}{l}\text { [23] } \\
\text { Dehghan } \\
\text { B. }\end{array}$ & Spiral Coil & $\begin{array}{l}\mathrm{D}=0.45 \mathrm{~m} \\
\mathrm{~L}=60 \mathrm{~m}\end{array}$ & COMSOL & $\checkmark$ & & $\checkmark$ & $\begin{array}{l}\text { Spiral ground heat exchangers have high } \\
\text { efficiency and low costs. } \\
\text { The recommended distance between piles is at } \\
\text { least } 6 \mathrm{~m} \text {. }\end{array}$ \\
\hline
\end{tabular}






\subsection{Analytical methods}

Analytical models often use methods designed for borehole heat exchangers (BHE), while heat transfer within energy piles presents critical differences compared to BHE, especially for large diameter piles (Table 2). Many studies have examined the heat transfer within ground heat exchangers under steadyflux conditions. This process can be easily analyzed by introducing the concept of thermal resistance, similar to the concept of electrical resistance. Loveridge et al. [35] presented the principal methods developed on two-dimensional and three-dimensional scales to calculate the thermal resistance of GHE 
pipes in the steady-state. However, the process of heat transfer within an energy pile is transient. So, the application of a time-independent approach can lead to an over-prediction of temperature changes underground and uncertainty regarding the system's thermal design [35]. Simultaneously, models derived from the G-function theory, such as line heat source models (LSM) and cylindrical heat source models (CSM), have been established to calculate the temperature change of a vertical heat source surrounded by a uniform ground $[32,36,37]$ (Figure 3 ). These models have been widely used in practice to treat the behavior of boreholes and energy piles for their simplicity and low computational time. However, the simplifications assumed by these models can make errors in the analysis of energy piles. Wang et al. [38] investigated the limitation of the homogeneous analytical models for energy piles numerically. The results showed that the assumption of a homogenous domain could lead to an incorrect estimate of heat transfer, particularly in short-term operation, and for large diameter piles [39].

Furthermore, the models do not address the effect of the backfill material's thermal mass, while this aspect can be critical for energy piles of sizeable concrete volume. According to Park et al. [17], the concrete's thermal capacity has a dominant effect on the thermal performance of energy piles in shortterm periods, even more than thermal conductivity. Therefore, thermal storage of heat within the pile concrete should be accurately specified, and its incorporation into analytical analysis and design software of energy pile needs to be considered. Man et al. enhanced the cylindrical source model to consider this aspect. The model showed a closer realistic analysis of pile heat exchangers compared to the classic models, especially at the long-term response, where the temperature curve tends to a steady-state distribution.

Nevertheless, it ignores the GHE geometry and applies uniform material properties for both concrete and ground. Some studies published analytical analysis for spiral heat exchangers. Cui et al. [40] developed the ring-coil heat source model (RSM) to analyze the transient thermal conduction around energy piles, including helical coils. The alternative model, based on the cylindrical heat source, simplifies the spiral tubes into separate rings but neglects the effect of the pile pitch. This assumption allows the temperature in each ring to tend to infinity, resulting in an unrealistic response to spiral pipes. Man et al. [37] overcome the gap of the ring model. They assumed the heat exchanger as a spiral line, where each pitch section releases heat. This spiral model with finite length can be considered a desirable tool for thermal analysis of spiral heat exchangers, as the model considers the radial dimension of the heat source and the heat capacity of the pile. However, the model still needs experimental and numerical validation.

Table 2.Aspects of differences between Boreholes and Energy piles

\begin{tabular}{ll}
\hline Boreholes & Energy piles \\
\hline Aspect ratio from 500 to 2000 & Aspect ratio from 15 to 50 \\
Negligible thermal mass & large thermal mass \\
Symmetric geometry in the ground & geometry Constrained by foundation piles location \\
Neglected thermal axial effects & Significant axial effects at short-term \\
Thermal steady-state analysis & Thermal transient state analysis
\end{tabular}




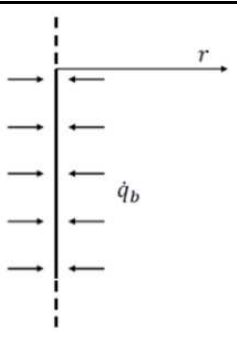

(a)

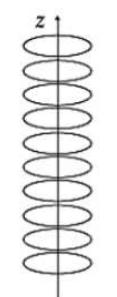

(e)

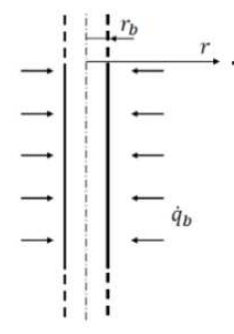

(b)

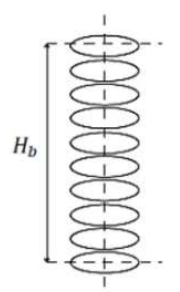

(f)

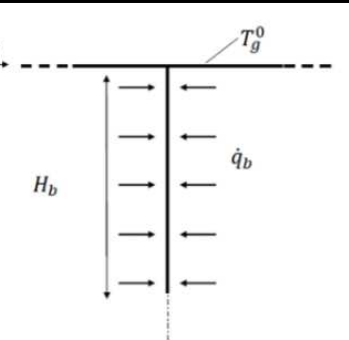

(c)

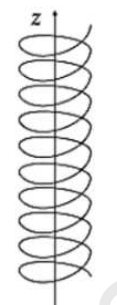

(g)

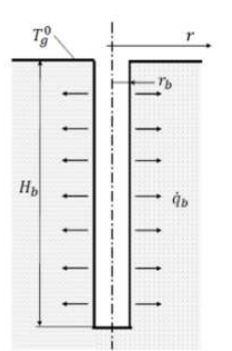

(d)

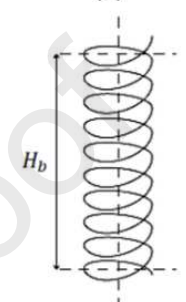

(h)

Figure 3. Schematic representation of the main analytical models for vertical GHE analysis: (a) ILSM, (b) ICSM, (c) FLSM, (d) SCSM, (e) IRSM, (f) FRSM, (g) ISSM, (h) FSSM

\subsection{Numerical methods}

Many numerical models have been developed in the past years to analyze energy piles' thermal performance, based mostly on finite element and finite volume methods [19,23,24,26,34]. Several reviews $[5,6,41,42]$ showed that numerical models are precise and realistic to simulate energy piles. Their advantages come from defining each system component and describing various boundary conditions and configuration states. They can also simulate the fluid flow along the pipe, considering the temperature change with the pile depth. As well, they can introduce the groundwater movement in the soil, the various soil layers, and the thermal capacities of different pile elements. Some studies proposed 3D numerical models to detect the heat transfer performance of energy piles $[31,43,44]$. Cui and Zhu [21] found a difference of only $12 \%$ in pile temperature between the detailed numerical model and the experimental results. However, most numerical studies adopted simplifications to reduce the high computational time desired for the discretization of the complex numerical models $[20,22,30,33,45]$. Mixed 1D-3D approaches have also been developed to reduce the complexity of full 3D models $[46,47]$. They simulate the heat transfer in the piles and the surrounding based on 3D approaches, while they simulate the heat and fluid flow inside the pipes based on 1D approaches. Caulk et al. [47] checked the 1D-3D model and found good agreement with experimental data. Besides, Park et al. [17] proposed an engineering chart to assess the heat transfer in energy piles, based on the concept of thermal resistance and design factors, resulting from parametric studies. The authors verified the accuracy of the chart values by performing CFD models for energy piles with multiple U-tube and coil-tube configurations. The results revealed a maximum error of $9 \%$ compared to CFD simulations. However, the chart admits some limitations. It is recommended to address a larger number of design parameters to assess the overall thermal behavior of energy piles. 


\section{Thermo-mechanical behavior of energy piles}

\subsection{State-of-the-art}

Temperature changes associated with geothermal processes pose additional challenges to structural and geotechnical engineers. The application of heating/cooling cycles causes thermal expansion and contractions of piles, affects their bearing capacity, and produces stresses and strains in their section $[48,49]$. The review of experimental tests executed full and small scales energy piles and centrifuge models leads to develop a general understanding of the mechanical behavior of pile foundations under thermal loading. Energy piles under thermal loading are subject to thermal stresses related to the intensity of the temperature changes, to the pile-bearing behavior, and the end-restraint conditions [50] [3] (Figure 4). Heating energy piles, during the cooling season, increases the compressive stresses in the piles between $40 \mathrm{KPa} /{ }^{\circ} \mathrm{C}$ and $360 \mathrm{KPa} /{ }^{\circ} \mathrm{C}$ while cooling, during the heating season, induces a reduction in compressive stresses of approximately $-15 \mathrm{KPa} /{ }^{\circ} \mathrm{C}$ to $-180 \mathrm{KPa} /{ }^{\circ} \mathrm{C}$ [16]. Fang et al. [51] observed a double increase in total axial stresses under thermo-mechanical loading compared to mechanical loading only. Di Donna and Laloui [52] found that the compressive stresses generated in energy piles during heating are lower than the limit state. However, during the cooling phase, they decrease, leading to a zone of tensile stresses at the pile tip. This can be attributed to the high-restrained pile subjected to significant cooling loads. Besides, thermal loads can also mobilize the resistance of the shaft in both the upper-half and lower-half of energy piles, causing variations in their bearing capacity. The heating loads can increase the bearing capacity of energy piles ranging from $13 \%$ to $16.4 \%$ [53] [54] [51], but the cooling loads decrease it by $8.7 \%$ according to Wang et al. [54]. Thermally-induced strains along energy piles are often reversible, developed mainly during the first thermal cycle, and accumulated with time $[55,56]$. However, the increment of these strain accumulations decreases with the increase in thermal cycles, where at the end of cycles, these strains are within the elastic range [57]. Kalantidou et al. [58] studied the behavior of an axially loaded pile during cooling-heating cycles. They found that the displacement-temperature curve is reversible and varies similarly to the thermal expansion curve of the pile. However, when the applied mechanical loads exceed $40 \%$ of the ultimate resistance, the irreversible settlement appears at the pile's toe in sandy soil. Other studies have also revealed similar results $[3,59]$. Therefore, the effect of the mechanical loading rate on the thermally-induced stresses is critical and should be strongly accounted for when designing energy piles, especially for values greater than $40 \%$. 


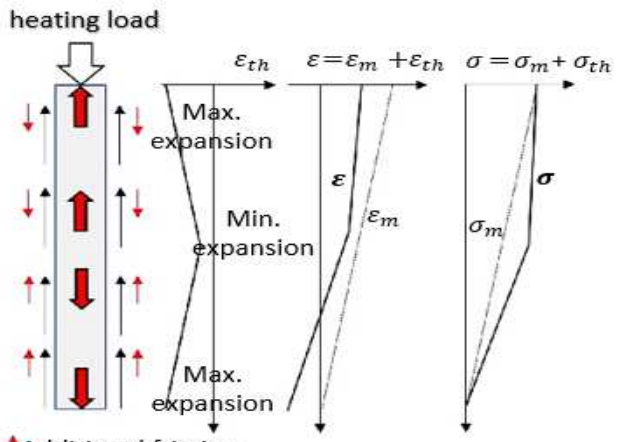

$\uparrow$ Additional friction by heating
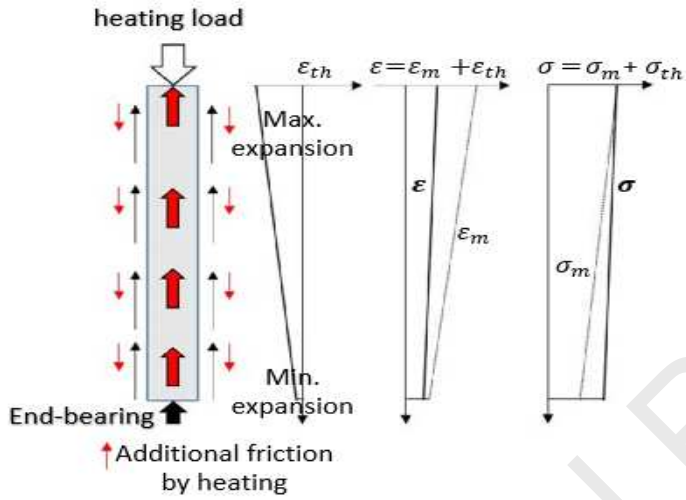

Cooling load

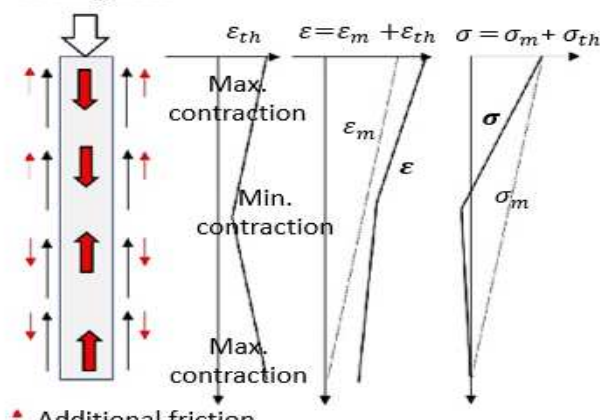
by cooling

(a)

(b)

Figure 4.Thermo-mechanical performance of (a) friction pile and (b) end-bearing pile [60].

\subsection{Analysis approach}

Full experiments reflect the actual behavior of energy piles subjected to thermal and mechanical loads [61]. However, when the in situ tests are not available, numerical studies can represent an alternative approach tool. These studies include two approaches of modeling: the first method uses load- transfer methods in a simplified one-dimensional model, where the second method uses the finite element method or the finite difference method in a complex three-dimensional model (Table 3).

\subsubsection{Load-transfer method}

The load-transfer ( $t-z)$ methods are used to estimate the axial behavior of energy piles. They discretize the pile into rigid elements connected by springs. Bourne-Webb et al. [5] summarized and analyzed the studies carried out in the literature on the load-transfer methods. Their advantages come from their simplicity to use in the practical design application. However, the assumptions used in these methods can lead to necessary limitations on the accurate description of the real energy pile response. These models assume minor temperature changes in the ground, which can be critical for long-time analysis.

Additionally, they do not consider the effects of thermal loading on the mechanical properties of soils. It can be an acceptable approximation for granular and stiff ground, but it is not applicable in clayey soils, where thermal consolidation can occur due to heating loads. The thermo-mechanical study of Civelek [62] on silty clay revealed this issue and confirmed that clayey soils show a thermo-elastic response in 
case of over-consolidation, where thermo-plastic response appears for the normally consolidated condition. Sutman et al. [63] compared three load-transfer approaches and found that they yield different results, although the same resistance, soil characteristics, and pile properties are assumed. The analysis of the $(\mathrm{t}-\mathrm{z})$ methods also showed a reduction in thermally-induced displacement compared to the actual behavior of the structure.

\subsubsection{Numerical method}

A full numerical thermo-hydro-mechanical model that considers all design aspects such as the mechanical boundary conditions, the behavior of each system element, the groundwater conditions, and material parameters is essential. However, the high computational time required for such analysis leads many authors to take simplifications regarding element modeling and boundary conditions [56,6468]. A comprehensive review of Bourne-Webb et al. [14] highlighted a shortcoming of some simplifications that can cause a false prediction of pile restraint and thus introducing errors in the calculation of internal stresses and pile displacements. They noted that assuming steady-state and ignoring hydraulic coupling would result in more significant pile displacement and fewer stress changes in the pile response. Gawecka et al. [69] highlighted this effect and showed how these assumptions increase the displacement of the pile head and reduce the change of axial stresses over time. Therefore, further validation is required regarding the assumptions used in numerical models to assess their accuracy to detect the thermo-mechanical response of energy piles.

Table 3. Recent studies on the thermo-mechanical behavior of energy piles.

\begin{tabular}{|c|c|c|c|c|c|c|c|c|}
\hline Reference & $\begin{array}{l}\text { Tempera } \\
\text { ture } \\
\text { range }\end{array}$ & Soil type & Pile size & $\begin{array}{l}\text { Method } \\
\text { and/or } \\
\text { software }\end{array}$ & $\begin{array}{l}\text { Nume } \\
\text { rical }\end{array}$ & $\begin{array}{c}\text { Analy } \\
\text { tical }\end{array}$ & $\begin{array}{l}\text { Experi } \\
\text { mental }\end{array}$ & Results \\
\hline $\begin{array}{l}\text { [63] } \\
\text { Sutman et } \\
\text { al. }\end{array}$ & $\Delta \mathrm{T}=35^{\circ} \mathrm{C}$ & Clay & $\begin{array}{l}\mathrm{D}=0.23 \mathrm{~m} \\
\mathrm{~L}=15.24 \mathrm{~m}\end{array}$ & $\begin{array}{l}\text { load- } \\
\text { transfer } \\
\text { method } \\
\text { CMOSOL }\end{array}$ & $\checkmark$ & $\sqrt{ }$ & & $\begin{array}{l}\text { The load-transfer method miscalculates } \\
\text { the thermally-induced displacement in } \\
\text { the energy pile. }\end{array}$ \\
\hline $\begin{array}{l}\text { [64] } \\
\text { Saggu }\end{array}$ & $\begin{array}{l}\Delta \mathrm{T}= \\
21^{\circ} \mathrm{C} \\
35^{\circ} \mathrm{C}\end{array}$ & Sand & $\begin{array}{l}D=0.5 m \\
1 m \\
L=15 m \\
20 m\end{array}$ & $\begin{array}{l}\text { FEM } \\
\text { Abaqus, } \\
\text { CASM }\end{array}$ & $\checkmark$ & & & $\begin{array}{l}\text { The pile length and the soil density have } \\
\text { significant effects on the pile behavior } \\
\text { under thermal loading. }\end{array}$ \\
\hline $\begin{array}{l}\text { [61] } \\
\text { Faizal et } \\
\text { al. }\end{array}$ & $\begin{array}{l}\mathrm{T}=5^{\circ} \mathrm{C}- \\
55^{\circ} \mathrm{C}\end{array}$ & Sand & $\begin{array}{l}\mathrm{D}=0.6 \mathrm{~m} \\
\mathrm{~L}=16.1 \mathrm{~m}\end{array}$ & Field test & & & $\checkmark$ & $\begin{array}{l}\text { Thermal stresses in the radial direction } \\
\text { are negligible compared to those in the } \\
\text { axial direction. } \\
\text { Ratcheting response appears during } \\
\text { initial thermal cycles. }\end{array}$ \\
\hline $\begin{array}{l}{[54]} \\
\text { Wang et } \\
\text { al. }\end{array}$ & $\begin{array}{l}\Delta \mathrm{T}=- \\
20^{\circ} \mathrm{C} \\
40^{\circ} \mathrm{C}\end{array}$ & $\begin{array}{l}\text { Sand, silty } \\
\text { clay }\end{array}$ & $\begin{array}{l}D=1.06 m \\
L=25.8 m\end{array}$ & $\begin{array}{l}\text { Field test } \\
\text { FEM } \\
\text { Abaqus }\end{array}$ & $\checkmark$ & & $\checkmark$ & $\begin{array}{l}\text { The bearing capacity decreases by } 8.7 \% \\
\text { during cooling and increases by } 13.2 \% \\
\text { during heating. }\end{array}$ \\
\hline $\begin{array}{l}{[70]} \\
\text { Rotta } \\
\text { Loria and } \\
\text { Laloui }\end{array}$ & $\begin{array}{l}\Delta \mathrm{T}=5^{\circ} \mathrm{C}- \\
20^{\circ} \mathrm{C}\end{array}$ & $\begin{array}{l}\text { Multiple } \\
\text { layers }\end{array}$ & $\begin{array}{l}D=0.9 m \\
L=28 m\end{array}$ & $\begin{array}{l}\text { Field test } \\
\text { FEM } \\
\text { 3D } \\
\text { CMOSOL }\end{array}$ & $\checkmark$ & & $\checkmark$ & $\begin{array}{l}\text { Increasing the number of activated } \\
\text { energy piles increases the thermal } \\
\text { strains and decreases the thermal } \\
\text { stresses in the foundation. }\end{array}$ \\
\hline $\begin{array}{l}\text { [71] } \\
\text { Ouyang et } \\
\text { al. }\end{array}$ & $\begin{array}{l}\mathrm{T}=8^{\circ} \mathrm{C}- \\
19^{\circ} \mathrm{C}\end{array}$ & clay & $\begin{array}{l}\mathrm{D}=0.3 \mathrm{~m} \\
\mathrm{~L}=25 \mathrm{~m}\end{array}$ & $\begin{array}{l}\text { load- } \\
\text { transfer } \\
\text { method } \\
\text { TRT }\end{array}$ & & $\checkmark$ & $\checkmark$ & $\begin{array}{l}\text { the experimental test showed thermally- } \\
\text { induced cracks. }\end{array}$ \\
\hline $\begin{array}{l}\text { [72] } \\
\text { Wu et al. }\end{array}$ & $\begin{array}{l}\mathrm{T}=5^{\circ} \mathrm{C}- \\
45^{\circ} \mathrm{C}\end{array}$ & $\begin{array}{l}\text { NC } \\
\text { Saturated } \\
\text { clay }\end{array}$ & $\begin{array}{l}\mathrm{D}=23 \mathrm{~mm} \\
\mathrm{~L}=550 \mathrm{~mm}\end{array}$ & $\begin{array}{l}\text { Laboratory } \\
\text { test }\end{array}$ & & & $\checkmark$ & $\begin{array}{l}\text { The presence of the pile group and the } \\
\text { pile cap reduces the irreversible pile } \\
\text { head displacement. }\end{array}$ \\
\hline $\begin{array}{l}\text { [51] } \\
\text { Fang et al. }\end{array}$ & $\begin{array}{l}\mathrm{T}=15^{\circ} \mathrm{C}- \\
60^{\circ} \mathrm{C}\end{array}$ & sandy clay & $\begin{array}{l}\mathrm{D}=0.6 \mathrm{~m} \\
\mathrm{~L}=16.1 \mathrm{~m}\end{array}$ & $\begin{array}{l}\text { Centrifuge } \\
\text { test }\end{array}$ & & & $\checkmark$ & $\begin{array}{l}\text { The bearing capacity of energy piles } \\
\text { increases by } 16.4 \% \text { in the heating mode }\end{array}$ \\
\hline
\end{tabular}




\begin{tabular}{|c|c|c|c|c|c|c|c|}
\hline & & & & & & & $\begin{array}{l}\text { for } \Delta \mathrm{T}=+29^{\circ} \mathrm{C} \text { and by } 30 \% \text { for } \Delta \mathrm{T}=+41 \\
{ }^{\circ} \mathrm{C} \text {. }\end{array}$ \\
\hline $\begin{array}{l}{[56]} \\
\text { Bao et al. }\end{array}$ & $\begin{array}{l}\mathrm{T}=28^{\circ} \mathrm{C}- \\
50^{\circ} \mathrm{C}\end{array}$ & $\begin{array}{l}\text { Saturated } \\
\text { Clay }\end{array}$ & $\begin{array}{l}D=0.2 \mathrm{~m} \\
\mathrm{~L}=1.25 \mathrm{~m} \\
0.95 \mathrm{~m}\end{array}$ & $\begin{array}{l}\text { Laboratory } \\
\text { Test } \\
\text { 2D FE-FD }\end{array}$ & $\checkmark$ & $\checkmark$ & $\begin{array}{l}\text { the pile settlement reduces during the } \\
\text { pure heating cycle. } \\
\text { Unrecoverable plastic deformation } \\
\text { appears during the cooling cycle. }\end{array}$ \\
\hline $\begin{array}{l}\text { [53] } \\
\text { Huang et } \\
\text { al. }\end{array}$ & $\begin{array}{l}\mathrm{T}=5^{\circ} \mathrm{C}- \\
50^{\circ} \mathrm{C}\end{array}$ & $\begin{array}{l}\text { Saturated } \\
\text { Sand }\end{array}$ & $\begin{array}{l}D=50 \mathrm{~mm} \\
L=1 \mathrm{~m}\end{array}$ & $\begin{array}{l}\text { Laboratory } \\
\text { Test }\end{array}$ & $\checkmark$ & $\checkmark$ & $\begin{array}{l}\text { Plastic displacement appears after one } \\
\text { heating cycle. }\end{array}$ \\
\hline $\begin{array}{l}\text { [66] } \\
\text { Rammal } \\
\text { et al. }\end{array}$ & $\begin{array}{l}\mathrm{T}=2^{\circ} \mathrm{C}- \\
26^{\circ} \mathrm{C}\end{array}$ & $\begin{array}{l}\text { Saturated } \\
\text { Sand }\end{array}$ & $\begin{array}{l}\mathrm{D}=0.41 \mathrm{~m} \\
\mathrm{~L}=12 \mathrm{~m}\end{array}$ & $\begin{array}{l}\text { FDM } \\
\text { FLAC3D }\end{array}$ & $\checkmark$ & & $\begin{array}{l}\text { Study the heating and the cooling cycles, } \\
\text { independently, underestimates the pile } \\
\text { displacement. }\end{array}$ \\
\hline $\begin{array}{l}{[68]} \\
\text { Adinolfi et } \\
\text { al. }\end{array}$ & $\begin{array}{l}\mathrm{T}=10^{\circ} \mathrm{C}- \\
28^{\circ} \mathrm{C}\end{array}$ & Clay & $\begin{array}{l}D=0.3 m \\
0.4 m \\
L=23 m \\
11.4 m\end{array}$ & $\begin{array}{l}\text { 2D FEM } \\
\text { COMSOL }\end{array}$ & $\checkmark$ & & $\begin{array}{l}\text { Ignoring daily thermal cycles can } \\
\text { overestimate the heat transfer. } \\
\text { The computational time of the } \\
\text { numerical model is fifteen times longer } \\
\text { than that of the simplified one. }\end{array}$ \\
\hline $\begin{array}{l}\text { [67] } \\
\text { Xiao et al. }\end{array}$ & $\begin{array}{l}\mathrm{T}=- \\
18^{\circ} \mathrm{C}- \\
+20^{\circ} \mathrm{C}\end{array}$ & NC Clay & $\mathrm{D}=95 \mathrm{~mm}$ & $\begin{array}{l}\text { Thermal } \\
\text { Borehole } \\
\text { Shear Test }\end{array}$ & & $\checkmark$ & $\begin{array}{l}\text { Significant reduction in the shear } \\
\text { strength at the pile/soil interface due to } \\
\text { temperature and radial displacement } \\
\text { under thermal cycles. }\end{array}$ \\
\hline $\begin{array}{l}{[73]} \\
\text { Rotta } \\
\text { Loria et al. }\end{array}$ & & & & $\begin{array}{l}\text { layer model } \\
\text { continuous } \\
\text { model } \\
\text { 3D FEM }\end{array}$ & $\checkmark$ & & $\begin{array}{l}\text { Higher accuracy of FEM compared to the } \\
\text { load-transfer method to account for the } \\
\text { interactions of energy pile groups. }\end{array}$ \\
\hline $\begin{array}{l}\text { [74] } \\
\text { Nguyen et } \\
\text { al. }\end{array}$ & $\begin{array}{l}\mathrm{T}=19^{\circ} \mathrm{C}- \\
21^{\circ} \mathrm{C}\end{array}$ & Dry sand & $\begin{array}{l}\mathrm{D}=20 \mathrm{~mm} \\
\mathrm{~L}=600 \mathrm{~mm}\end{array}$ & $\begin{array}{l}\text { Laboratory } \\
\text { test }\end{array}$ & & $\checkmark$ & $\begin{array}{l}\text { The increase in cycle number reduces } \\
\text { the irreversible settlement. } \\
\text { Higher axial force at the end of heating } \\
\text { compared to cooling. }\end{array}$ \\
\hline $\begin{array}{l}\text { [55] } \\
\text { Luo et al. }\end{array}$ & $\begin{array}{l}\mathrm{T}=10^{\circ} \mathrm{C}- \\
30^{\circ} \mathrm{C}\end{array}$ & Sandy clay & $\begin{array}{l}D=0.6 \mathrm{~m} \\
\mathrm{~L}=18.5 \mathrm{~m}\end{array}$ & TRT & & $\checkmark$ & $\begin{array}{l}\text { The temperature change and the } \\
\text { restraint condition affect the expansion } \\
\text { and contraction of the energy piles. } \\
\text { The deformation of energy piles is } \\
\text { elastic. }\end{array}$ \\
\hline $\begin{array}{l}{[75]} \\
\text { Wang et } \\
\text { al. }\end{array}$ & $\begin{array}{l}\mathrm{T}=11^{\circ} \mathrm{C}- \\
55^{\circ} \mathrm{C}\end{array}$ & Dry sand & $\begin{array}{l}\mathrm{D}=104 \mathrm{~mm} \\
\mathrm{~L}=1.6 \mathrm{~m}\end{array}$ & $\begin{array}{l}\text { Laboratory } \\
\text { test }\end{array}$ & & $\checkmark$ & $\begin{array}{l}\text { Thermal strains are higher for piles with } \\
\text { W-tube compared to piles with spiral } \\
\text { coil and U-tube. }\end{array}$ \\
\hline $\begin{array}{l}\text { [65] } \\
\text { Alberdi- } \\
\text { Pagola et } \\
\text { al. }\end{array}$ & $\begin{array}{l}\mathrm{T}=4^{\circ} \mathrm{C}- \\
16^{\circ} \mathrm{C}\end{array}$ & Sand & $\begin{array}{l}D=0.15 \mathrm{~m} \\
L=15 \mathrm{~m}\end{array}$ & $\begin{array}{l}\text { 3D FEM } \\
\text { COMSOL }\end{array}$ & $\checkmark$ & & $\begin{array}{l}\text { No significant structural effects of } \\
\text { thermal cycles on energy piles after one } \\
\text { year of operation for temperature } \\
\text { variation within } 2^{\circ} \mathrm{C} \text {. }\end{array}$ \\
\hline $\begin{array}{l}\text { [69] } \\
\text { Gawecka } \\
\text { et al. }\end{array}$ & $\begin{array}{l}\mathrm{T}=-6^{\circ} \mathrm{C}- \\
+56^{\circ} \mathrm{C}\end{array}$ & Clay & $\begin{array}{l}D=0.55 \mathrm{~m} \\
L=23 \mathrm{~m}\end{array}$ & $\begin{array}{l}\text { FEM } \\
\text { ICFEP }\end{array}$ & $\checkmark$ & & $\begin{array}{l}\text { Considerable tensile axial stress appears } \\
\text { in the pile during cooling mode. } \\
\text { Overestimation of the pile behavior } \\
\text { using the load-transfer method and } \\
\text { when neglecting the transient state of } \\
\text { the thermal loads. }\end{array}$ \\
\hline
\end{tabular}

\subsection{Concrete behavior in energy piles}

Understanding the accurate response of concrete under thermal loads is complex due to the non-linear and heterogeneous nature of concrete. The temperature changes can significantly affect the density, thermal diffusion, and compressive strength of concrete due to the change in permeability and porosity [50]. Besides, contraction and dilatation of cement can lead to thermal cracks in cement-based materials, resulting in reduced concrete durability. The effect of cracks becomes critical when tensile stresses occur in concrete and exceed its ultimate strength [71]. This behavior can pose a significant interaction problem between the mechanical and thermal performance of the geothermal system, especially for long-term operation. However, to the authors' knowledge, there is not yet a detailed 
approach to integrate various properties of concrete into modeling to study their effects on the thermomechanical behavior of energy piles at different time scales.

\subsection{Adjacent energy piles}

The heat transfer capacity of a single pile is usually insufficient to cover the heating and cooling loads of a building. Thus, buildings require the activation of a group of piles to meet the thermal loads. In this regard, the load-transfer method has been modified to consider the interaction between adjacent piles [76]. The interaction factor method has also been reported in the literature to find the displacement response of pile groups exposed to cooling and heating. It consists of analyzing the interactions between two adjacent piles, then superimposing the individual impacts on a group. Rotta and Laloui [77] validated the interaction factor method by a 3D numerical model. However, the method is developed only for energy piles free of mechanical loads and free to move at their head where they are fully restricted at the tip. Therefore, using this method for floating pile groups can underestimate the vertical displacements.

On the other hand, some numerical models have been performed to investigate the effect of group action caused by thermally-activated piles $[70,73,78]$. The results showed that the increase in the number of energy piles decreases the pile stresses but increases the displacements of the foundation to critical values. Wu et al. [72] introduced the effect of the pile cap on the thermo-mechanical behavior of energy piles. They found that the pile cap poses additional restrains on the energy piles, resulting in smaller irreversible head displacements compared to that without the pile cap. The effect of the raft foundation appears more critical, as presented in the numerical study of Salciarini et al. [79]. The presence of a relatively rigid raft results in axial stresses in non-active piles in the same order as that of thermally active piles, even when the latter are relatively spaced, and the temperature variations in the non-active piles are small. The changes in strains and stresses of a pile group are related to various variables influencing the interaction between piles. The soil young's modulus ratio, the spacing between piles, the pile-soil stiffness ratio, the soil-pile thermal expansion coefficient ratio, and the pile slenderness ratio are reported [77] [80]. However, further information is still required to find the effect of these variables on both active and non-active pile behavior. Detecting the proper position and the number of active energy piles is also an essential problem that should be investigated.

\section{Current Trends in energy piles design parameters}

The efficiency of energy piles depends on the design parameters of the entire system (Figure 5). So, improving the thermal properties of each element leads to better thermal performance. The following section provides a broad review of most published parametric studies. It improves the heat transfer efficiency between GHE and the ground. 


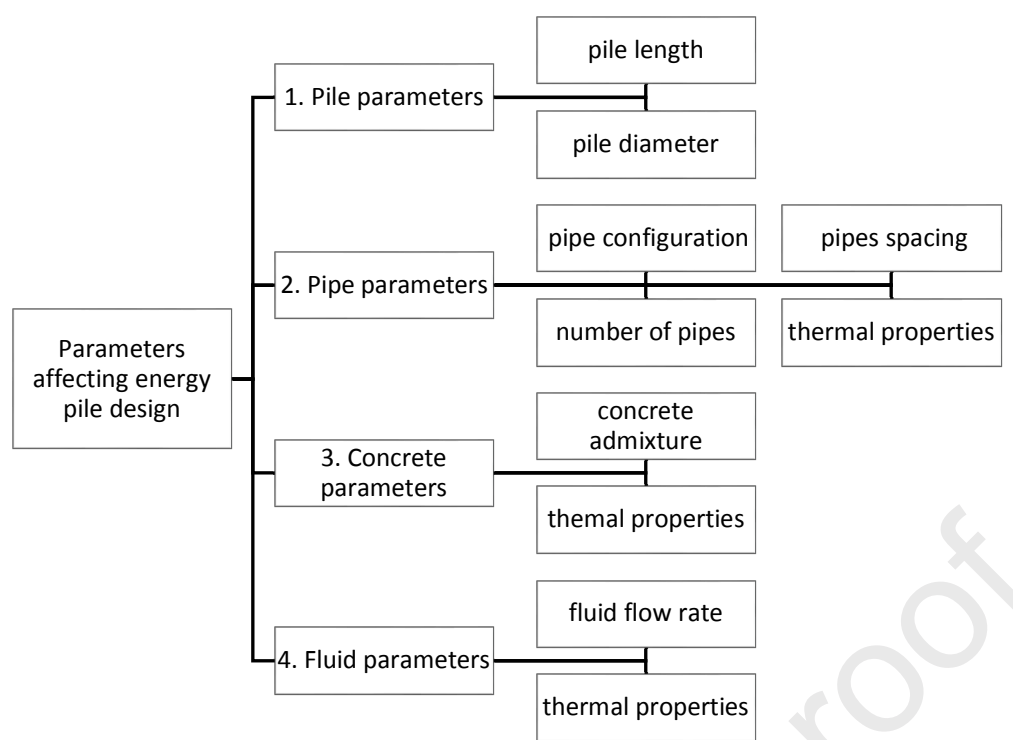

Figure 5. Parameters affecting energy piles design

\subsection{Pile design}

The efficiency of heat transfer increases with longer piles (Figure 6). Using larger diameter piles also has a positive effect, as it allows more GHE pipes to be installed. It reduces the pile thermal resistance and so on increases the heat transfer, but on the condition of preventing pipe-to-pipe interactions [81]. However, from a mechanical perspective, the additional thermal loads, due to the improvement in thermal performance, can increase the axial stresses of the foundation. So, any change in the design of the energy piles should take the mechanical side-effects.

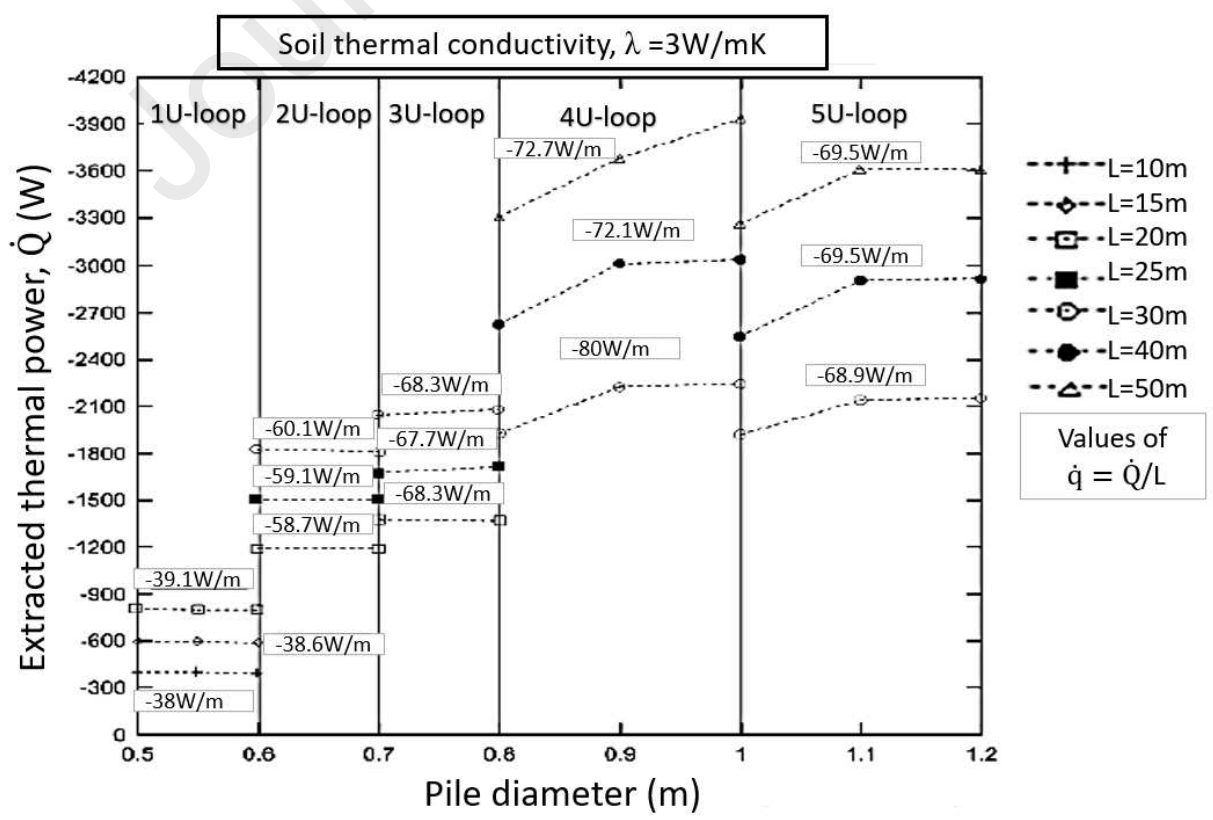

Figure 6. The effect of the diameter and length of the energy piles on their thermal performance [16] 


\subsection{Pipe design}

\subsubsection{Pipe configurations}

The configurations of vertical GHE pipes installed in an energy pile, as in a borehole, can be classified based on their cross-sectional geometry and the pathway taken by the fluid in the flow channels to exchange heat with the ground (Figure 7).

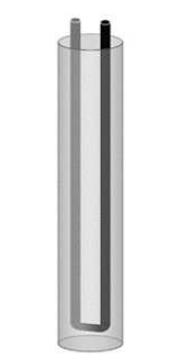

U-shaped pipe

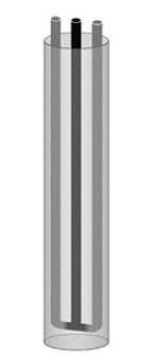

indirect double pipe
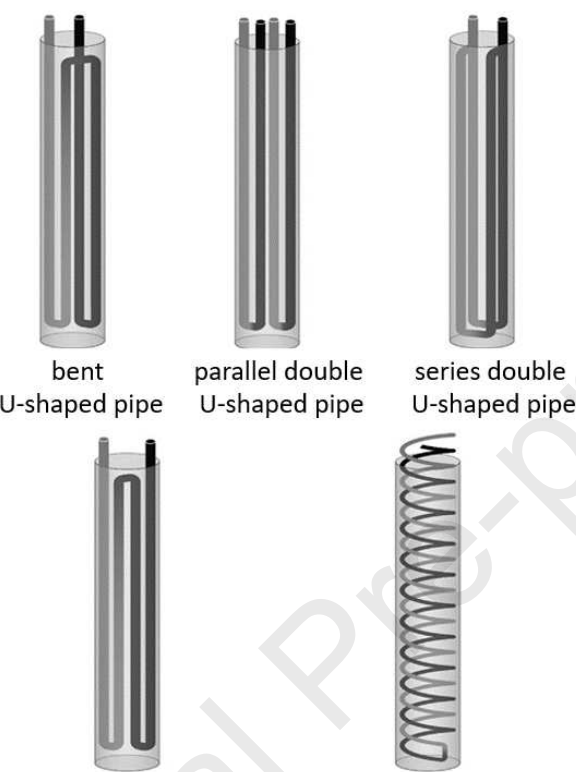

W-shaped pipe

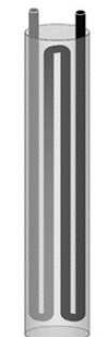

Figure 7. Pipe configurations for energy piles [16]

Changes in the pipe configuration play an essential role in thermal system performance. Generally, these pipes take the form of $\mathrm{U}, \mathrm{W}$, or spiral coils fixed to the reinforcement cage of an energy pile. For approximately thirty years, the single U-pipe has been the industry standard and the most commonly used for heat exchange in boreholes, as in energy piles. This popularity goes to the simplicity of U-tube design and ease of transport, as well as its ease of installation compared to other alternatives [82]. Wpipe heat exchangers have also been widely used in energy piles. However, although they have a higher thermal transfer capacity than those provided by U-pipes [3,83], the risk of air accumulation at the top of the W-tube [28] and its complicated installation compared to the U-tube can be the reasons for being less commonly used. The single U-tube and W-tube have been extended to double, triple, or multiple tubes to increase the effectiveness of heat exchange. The application of spiral (or helix) heat exchangers in energy piles has also attracted considerable attention. Providing high thermal efficiency, preventing airlock, and limiting thermal short-circuiting are the advantages that have led some studies to consider the spiral shape as the best configuration of the pile heat exchanger [23,84]. According to the thermal analysis done by Zarrella et al. [85] for short-timescales, the spiral coil provided a higher thermal transfer performance of $23 \%$ at the peak load than the pile with triple U-tube, but only a $9 \%$ increase in the normal state. Luo et al. [86] demonstrated that the spiral type after one year of operation achieved a thermal production of $90 \%$ and $96 \%$ compared with triple $U$ - and double $\mathrm{W}$ - types, but it was 1.4 times 
higher than double U-types (Figure 8). For the large-diameter energy piles, where more than 5-pairs of U-tubes can be installed, Park et al. [39] revealed that the heat exchanger pipes in helix shape have the optimal configuration, given the economic feasibility and the thermal performance. Nevertheless, the application of this shape is still limited because of the difficulties associated with its installation, especially in piles of small diameters [16].

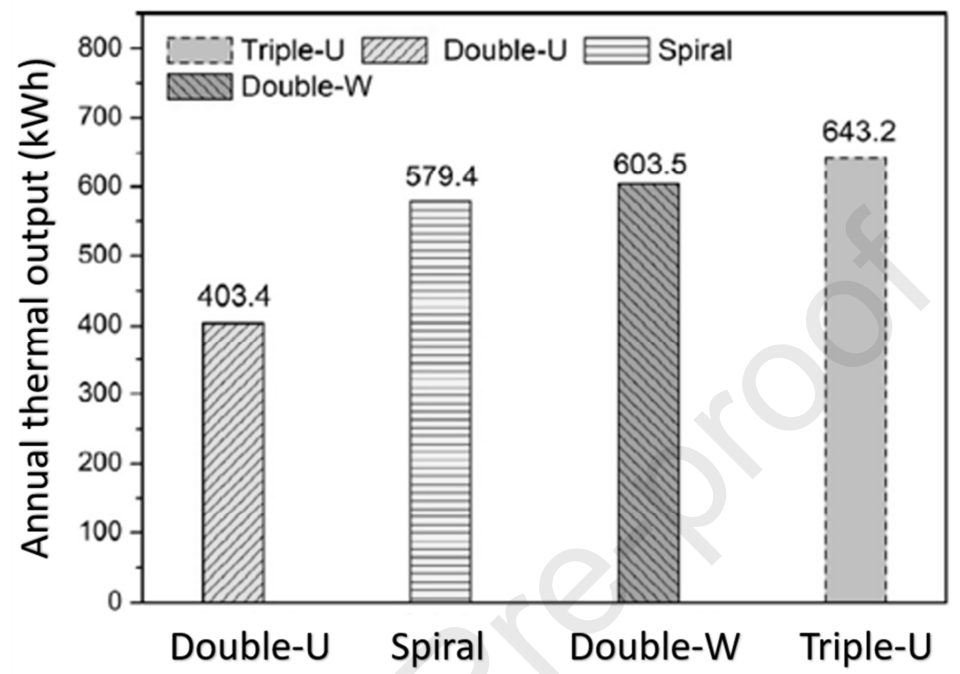

Figure 8. The effect of the pipe configuration on the thermal performance of energy piles [86]

Increasing the number of GHE pipes in an energy pile is advantageous. However, it becomes unfavorable when thermal interferences occur between the adjacent pipe loops [87]. Many studies emphasized the need to consider the effect of these interactions on heat transfer efficiency $[12,43,47,81,88]$. Lee and Lam [88] found that increasing the spacing between GHE pipes in an energy pile improves the thermal efficiency. However, the sensitivity analysis conducted by Caulk et al. [47] showed a gradual decrease in the rate of heat transfer per meter length after a certain distance (Figure 9). The study also showed lower thermal performance when the pipes are more plunged to the center of the pile. In this regard, Loveridge and Powrie [81] specified a typical range of pipe spacing from $250 \mathrm{~mm}$ to $300 \mathrm{~mm}$ to reduce heat transfer between GHE pipes and meet the thermal requirements. Therefore, to create an optimal geometry for heat exchangers in an energy pile with $\mathrm{U}-/ \mathrm{W}$ - configurations, it is recommended to install multiple GHE pipes with minimum shank spacing of $250 \mathrm{~mm}$. Besides, ground heat exchangers should be attached to the pile reinforcement cage to minimize the impact of the concrete cover around the pipes. 


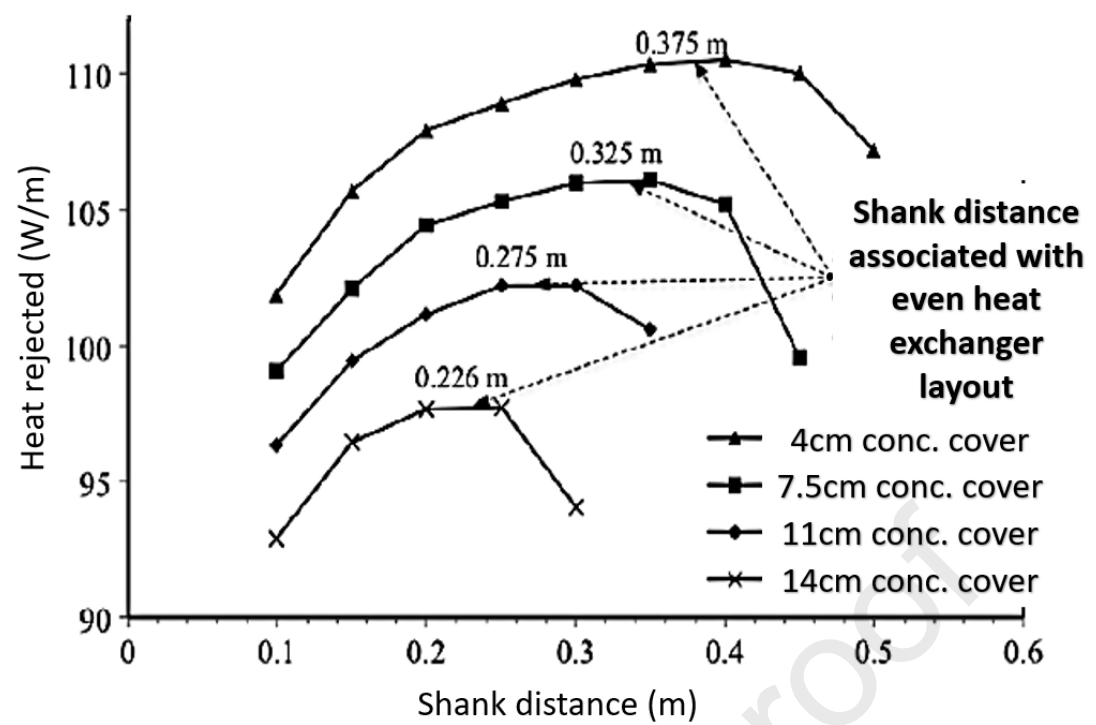

Figure 9. The effect of the shank distance and the concrete cover on the thermal performance of energy piles [47]

For helix heat exchangers, Zhao et al. [89] studied the effect of spiral pitch on the thermal behavior of energy piles. They proved that reducing the pitch size increases the heat transfer capacity. However, the use of smaller values less than $250 \mathrm{~mm}$ can cause excessive pressure drops and significant thermal interferences $[27,46]$. To weaken these effects, Huang et al. [27] proposed a novel truncated cone helix energy pile. The laboratory investigations found a higher thermal efficiency of the novel energy pile than the conventional ones. They also showed better performance by setting a more significant cone angle. However, the complex constructability of this form seems impractical in reality. Alternatively, it needs further structural and economic feasibility analysis.

\subsubsection{Pipe characteristics}

The pipes used in geothermal applications are subject to specific standards adopted during manufacturing. In general, they are polyethylene pipes [82], have a diameter ranging between $20 \mathrm{~mm}$ (DN20) and 40mm (DN40) [90]. For GHE pipes deeper than 150m, DN40 is the most used. However, for shallow energy systems of depth less than $60 \mathrm{~m}$, such as energy piles, the use of large pipe diameters is sometimes unfeasible due to the additional amount of pumping power required to increase the flow rate [12]. Table 4 summarizes the general properties of the main pipe types used in practice.

Table 4. Properties of some plastic heat exchanger pipes [82]

\begin{tabular}{lcccc}
\hline Type & $\begin{array}{c}\text { Outer diameter } \\
(\mathbf{m m})\end{array}$ & $\begin{array}{c}\text { Wall thickness } \\
(\mathbf{m m})\end{array}$ & $\begin{array}{c}\text { Thermal conductivity } \\
(\mathbf{W} /(\mathbf{m K}))\end{array}$ \\
\hline PE DN20 PN12 & 20 & 2.0 & 0.42 & $\begin{array}{c}\text { Thermal resistance } \\
(\mathbf{K} /(\mathbf{W} / \mathbf{m}))\end{array}$ \\
PE DN25 PN8 & 25 & 2.0 & 0.42 & 0.085 \\
PE DN25 PN12 & 25 & 2.3 & 0.42 & 0.066 \\
PE DN32 PN8 & 32 & 2.0 & 0.42 & 0.077 \\
PE DN32 PN12 & 32 & 3.0 & 0.42 & 0.051 \\
PE DN40 PN8 & 40 & 2.3 & 0.42 & 0.079 \\
PE DN40 PN12 & 40 & 3.7 & 0.42 & 0.046 \\
\hline
\end{tabular}

$\mathrm{PE}=$ polyethylene

$\mathrm{DN}=$ diameter - nominal

$\mathrm{PN}=$ pressure - nominal (in bars) 


\subsection{Concrete design}

Providing high mechanical properties of concrete is one of the principal objectives to maintain the strength and durability required of the structure. For energy pile systems, the thermal properties of concrete are also important due to their positive impact on the efficiency of heat transfer between the GHE pipes and the surrounding soil. Concrete has thermal conductivity values from $1 \mathrm{~W} / \mathrm{m}$. $\mathrm{K}$ to over $4 \mathrm{~W} / \mathrm{mK}$, depending on the cement/aggregate ratio, aggregate type, and moisture content [91,92]. The high aggregate ratio improves the thermal conductivity of the concrete [93]. However, the high cement content required for high-strength concrete mixtures can reduce it. Besides, adding additive materials such as fly-ash to improve the workability and durability of concrete can have a supplementary negative impact on thermal conductivity degradation by over $20 \%[46,91]$. Alternatively, Carotenuto et al. [46] found that the thermal performance of energy piles increases by $42 \%$ with an increase in the thermal conductivity of concrete from $1.2 \mathrm{~W} / \mathrm{mK}$ to $2.5 \mathrm{~W} / \mathrm{mK}$. Therefore, many studies have proposed improvements for this parameter. Li et al. [24] suggested adding graphite powder to cement paste. The results of laboratory testing and numerical study exhibit a significant improvement in the heat transfer with increased graphite content under the same environmental temperature. Laing et al. [94] showed that mixing concrete with heat transfer materials such as graphite and aluminum can provide required heating and cooling with fewer pipe heat exchangers of shorter length. Yang et al. [95] proposed combining graphite with the phase change material (PCM) in concrete to benefit from the high thermal conductivity of graphite and the high heat storage capacity of PCM. However, the addition of a large amount of graphite to improve the thermal conductivity regardless of the study of their mechanical side-effects on the structure can be critical. Guo et al. [96] found an excessive reduction in compressive and flexural strengths of concrete by $50 \%$ when graphite was $5 \%$ of concrete content due to the increase in porosity and void volume (Figure 10$)$. Therefore, some authors [11,97,98] proposed adding materials that have high strength and thermal conductivity, such as carbon fiber, copper slag, and steel fiber. In conclusion, adding thermally conductive materials to the concrete mix to improve the thermal properties of concrete is beneficial. Nevertheless, structural and economic feasibility studies are essential to maintain the compressive strength of concrete and to provide the cost-effectiveness of the structure.
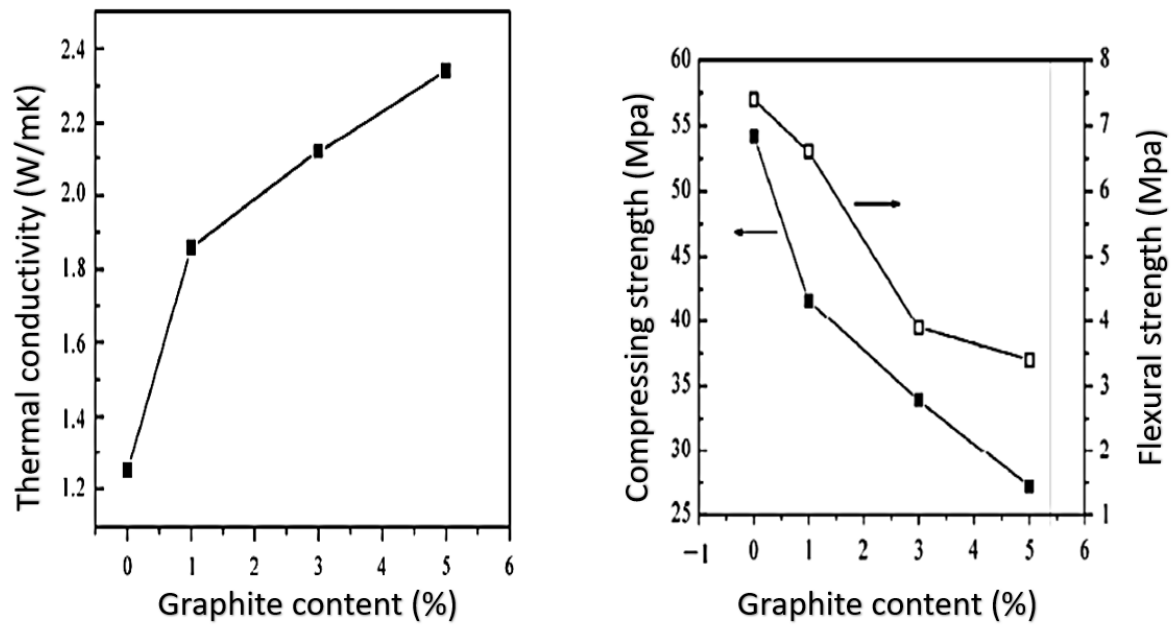
Figure 10. the effect of graphite content on thermal conductivity, compressive and flexural strength of concrete [96]

\subsection{Fluid design}

\subsubsection{Fluid flow}

The fluid flow behavior that is laminar or turbulent is an influential factor in the convective heat transfer efficiency between the fluid and the inner wall of GHE [99]. It is characterized by the Reynolds number (Re), which increases by increasing the pipe diameter and fluid velocity or decreasing fluid viscosity [100]. Reynolds number values below 2300 produce laminar flow where values above 4000 produce turbulent flow. Using a turbulent flow rate improves the heat transfer rate per meter of length between the pipe and ground. It can also reduce the heat transfer between the upward and downward flowpipes, and prevent the thermal short-circuiting that occurs at low laminar conditions [43,82]. However, according to Park et al. [17], excessive fast flow during full turbulence does not allow enough contact time for heat exchange and thus reduces thermal efficiency.

Moreover, increasing the pump performance to achieve turbulence leads to higher energy consumption by the heat pump and therefore increases the operational costs of the system[86]. Consequently, optimizing the fluid flow rate is necessary for both thermal performance and economic feasibility. Kavanaugh and Rafferty [90] recommended in the ASHRAE manual to use fluid flow rate in the transient conditions, for the Reynolds number between 2500 and 3000, which can be a compromise between thermal performance and power requirements of the heat pump.

\subsubsection{Fluid properties}

Water is the primary fluid used in heat exchangers for heat transfer, but it can be mixed with an antifreeze solution such as propylene glycol and ethylene glycol to avoid freezing fluid when the temperature falls below zero in the heat exchanger tubes [101]. However, the increased concentration of the water-glycol mixture significantly increases the fluid viscosity and thus the laminar zone, decreasing heat transfer (Table 5). Therefore, the optimal proportion of any admixture should avoid freezing, prevent excessive viscosity, and improve thermal performance without significantly increasing operational costs.

Table 5. Properties of the heat transfer fluids [101]

\begin{tabular}{lccccc}
\hline Fluid & $\begin{array}{c}\text { Freezing point } \\
\left({ }^{\circ} \mathrm{C}\right)\end{array}$ & $\begin{array}{c}\text { Normal boiling } \\
\text { point }\left({ }^{\circ} \mathrm{C}\right)\end{array}$ & $\begin{array}{c}\text { Viscosity at } 20^{\circ} \mathrm{C} \\
\text { (centipoise) }\end{array}$ & $\begin{array}{c}\text { Thermal } \\
\text { conductivity }(\mathrm{W} /(\mathrm{mK}))\end{array}$ & $\begin{array}{c}\text { The specific heat } \\
\text { at } 20^{\circ} \mathrm{C}(\mathrm{J} /(\mathrm{Kg} . \mathrm{K}))\end{array}$ \\
\hline Water & 0 & 100 & 1.01 & 0.609 & 0.258 \\
Ethylene glycol & -13 & 197 & 20.9 & 0.147 & 2.19 \\
Propylene glycol & -59 & 188 & 60.5 & 0.202 & 2.50 \\
Methanol & -98 & 64 & 0.6 & 2.47 \\
\hline
\end{tabular}

\subsection{Ground characteristics}

One of the fundamental design aspects of energy geo-structures is ground characteristics. The determination of the total GHE length is related to the amount of heat exchanged with the surrounding and so on to the thermal properties and the temperature profile of the ground. Therefore, improper evaluation of these parameters can lead to an overestimation or underestimation of the GHE design, consequently affecting the overall performance of the system. This becomes more critical with 
unbalanced heating and cooling loads [102]. The presence of groundwater flow also has a significant contribution in this direction due to convective heat transfer. The experimental study of You et al. [103] showed that groundwater flow not only increases the rate of heat transfer but also increases the soil thermal conductivity by $10 \%$, for a water flow velocity of $5.10^{-8} \mathrm{~m}^{2} / \mathrm{s}$. Table 6 summarizes the thermal ground database for unconsolidated sediments and rocks obtained from literature, direct measurements, and the European Cheap GSHPs-project, which combines experimental and literature values.

Table 6. Review of ground thermal properties [104]

\begin{tabular}{|c|c|c|c|c|c|c|c|c|c|c|c|c|}
\hline \multirow{4}{*}{ Material } & \multicolumn{4}{|c|}{ From Literature Review } & \multicolumn{5}{|c|}{ Directly measured } & \multirow{3}{*}{\multicolumn{3}{|c|}{$\begin{array}{c}\frac{\text { UNIPD-Cheap-GSHPs database }}{\lambda} \\
W^{-1} \mathrm{~K}^{-1}\end{array}$}} \\
\hline & \multirow{2}{*}{\multicolumn{2}{|c|}{$\begin{array}{c}\lambda \\
W m^{-1} K^{-1}\end{array}$}} & \multirow{3}{*}{$\begin{array}{c}\rho \mathrm{c}_{\mathrm{p}} \\
\mathrm{MJm}^{-3} \mathrm{~K}^{-1}\end{array}$} & \multirow{3}{*}{$\begin{array}{c} \\
10^{3} \mathrm{Kgm}^{-3}\end{array}$} & \multirow{2}{*}{\multicolumn{3}{|c|}{$\begin{array}{c}\lambda \\
W m^{-1} K^{-1}\end{array}$}} & \multirow{3}{*}{$\begin{array}{c}\rho \mathrm{c}_{\mathrm{p}} \\
\mathrm{MJm}^{-3} \mathrm{~K}^{-1}\end{array}$} & \multirow{3}{*}{$\begin{array}{c}\rho \\
10^{3} \mathrm{Kgm}^{-3}\end{array}$} & & & \\
\hline & & & & & & & & & & & & \\
\hline & $\min$ & $\max$ & & & $\min$ & $\max$ & REC. & & & $\min$ & $\max$ & 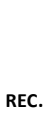 \\
\hline Sandstone & 0.72 & 6.50 & $1.8-2.6$ & $2.2-2.7$ & 1.03 & 4.54 & 2.00 & $2.06-2.28$ & $\begin{array}{l}2.43- \\
2.66\end{array}$ & 0.72 & 6.50 & 2.60 \\
\hline Clay-mudstone & 0.59 & 3.48 & 2.1-2.4 & $2.4-2.6$ & 1.47 & 3.21 & 2.54 & $1.80-2.23$ & 2.70 & 0.59 & 3.48 & 2.13 \\
\hline Limestone & 0.60 & 5.01 & 2.1-2.4 & $2.4-2.7$ & 2.42 & 4.41 & 2.88 & $1.81-2.22$ & $\begin{array}{l}2.35- \\
2.80\end{array}$ & 0.60 & 5.01 & 2.50 \\
\hline Granite & 1.49 & 4.45 & $2.1-3.0$ & $2.4-3.0$ & 2.02 & 3.68 & 3.13 & $1.80-2.12$ & $\begin{array}{l}2.66- \\
2.73\end{array}$ & 1.49 & 4.45 & 2.74 \\
\hline Marble & 0.98 & 5.98 & 2.0 & $2.5-2.8$ & & & & & & 0.98 & 5.98 & 2.50 \\
\hline Clean gravel, dry & 0.13 & 0.9 & $1.3-1.6$ & $1.8-2.2$ & 0.14 & 0.55 & 0.33 & + & & 0.14 & 0.9 & 0.4 \\
\hline $\begin{array}{l}\text { Heteromeric gravel } \\
\text { with sand, wet }\end{array}$ & 0.18 & 3.00 & & & 0.94 & 1.33 & 1.08 & & & 0.2 & 3.00 & 1.08 \\
\hline Medium sand, dry & 0.15 & 0.90 & $1.3-1.6$ & $1.8-2.2$ & 0.15 & 0.68 & 0.26 & $0.41-1.48$ & & 0.15 & 0.9 & 0.4 \\
\hline Medium sand, wet & 1.00 & 2.60 & $2.2-2.8$ & $1.9-2.3$ & 1.44 & 2.45 & 1.86 & $1.53-2.27$ & & 1.0 & 2.6 & 1.9 \\
\hline $\begin{array}{l}\text { Silty sand/sandy silt, } \\
\text { wet }\end{array}$ & 1.20 & 2.25 & & & 1.24 & 2.06 & 1.56 & $1.85-2.48$ & & 1.20 & 2.25 & 1.62 \\
\hline Silt, dry & 0.26 & 1.09 & $1.5-1.6$ & $1.8-2.0$ & 0.25 & 0.82 & 0.50 & $1.37-1.52$ & & 0.25 & 1.09 & 0.55 \\
\hline Silt and clayey silt, wet & 0.82 & 2.60 & $2.0-2.8$ & $2.0-2.2$ & 0.93 & 1.76 & 1.32 & $1.84-2.43$ & & 0.82 & 2.60 & 1.45 \\
\hline Clay, dry & 0.25 & 1.52 & $1.5-1.6$ & $1.8-2.0$ & 0.25 & 1.22 & 0.64 & $0.49-1.38$ & & 0.25 & 1.52 & 0.64 \\
\hline Plastic clay, wet & 0.60 & 1.90 & $2.0-2.8$ & $2.0-2.2$ & 0.87 & 1.39 & 1.03 & $0.62-2.67$ & & 0.60 & 1.90 & 1.10 \\
\hline
\end{tabular}

\section{Evaluation criteria of energy piles}

The development of a sustainable energy pile system involves a comprehensive analysis that goes beyond the thermal efficiency. Environmental impact and cost, with the thermal efficiency of the energy system, are essential and influential factors in evaluating the feasibility of this system and optimizing it. The high level of sustainability for an energy system specifically refers to an efficient and economically viable system with the least negative impact on the environment. To date, few guidelines have provided a reference to the indicators to be used to assess the overall performance of an energy pile-operating system. The evaluation of energy piles, from a thermal perspective, deals with the multi-criteria analysis of the ground-source heat pump system (GSHP) associated with these heat exchangers: energy, exergy, economy, and environmental criteria (denoted by $4 \mathrm{E}$ criteria) [105]. From the structural view, the possibility of failure of an energy pile system due to excessive expansion or extraction resulting from thermal exchange needs to be checked. In this section, the $4 \mathrm{E}-\mathrm{G}$ criteria relating to the design of energy piles, both thermally and mechanically, are reviewed (Table 7). 


\subsection{Energy criteria}

Improving energy performance is the principal target in the feasibility study of geothermal systems. Providing the thermal needs for buildings in an abundance and sustainable manner is the base objective of these systems. Therefore, increasing the efficiency of energy systems is essential. The performance of a GSHP is evaluated by comparing the energy delivered for buildings with the electricity consumed to operate the system [106]. Many terms determine the efficiency of the system, where the coefficient of performance (COP) is the most used (Table 7).

\subsection{Exergy criteria}

Generally, the most commonly used measurement when evaluating the efficiency of heat pump systems is energy efficiency, as mentioned above. However, exergy analysis is also needed for a more accurate analysis of the actual system performance in a specified environment. The exergy criterion determines the quality of different energy flows in each subsystem of energy systems $[107,108]$. Therefore, exergy analysis can be used to identify the primary sources of thermodynamic irreversibility and to minimize entropy generation during the heat transfer process [109]. Exergy loss values can quantify the reduction in the system's ability to deliver thermal energy in individual subsystems and the overall one, allowing for a more comprehensive assessment of the system's efficiency than energy analysis [110,111].

\subsection{Economic criteria}

An economic study is essential before installing a GSHP system associated with borehole heat exchangers due to the high cost of drilling boreholes. In contrast, this feature is less critical for energy piles because ground heat exchangers are mainly built into the pile foundation. So, there is no additional cost for drilling. Nevertheless, the overall economic analysis of the system, which includes investment, operation, and maintenance, provides the opportunity to assess economic feasibility accurately, especially for large-scale projects. The net present value (NPV) is a fundamental criterion in the economy to analyze the life cycle cost of a system from the payback period [112]. Some studies used NPV to examine the economic values of energy piles for different pipe configurations. However, for an accurate assessment, it is suitable to conduct an economic analysis of the entire system of GSHP instead of a single element of equipment. Other economic criteria can be used, such as the savings-toinvestment ratio (SIR), the life cycle cost (LCC), and the profitability index (PI) (Table 7).

\subsection{Environmental criteria}

Environmental concerns are an essential factor in sustainable development. Keeping a healthy environment preserves the system besides the surrounding environment. Operating a GSHP system without paying attention to this indicator can affect adjacent systems and the ecological environment with time. This aspect becomes critical with unbalanced heat exchange during the cooling and heating phases. In contrast, to date, none of the studies or references has provided indicators to assess this effect. However, some studies have used some factors that provided a general overview of the environmental impacts associated with the use of GSHP (Table 7). 


\subsection{Mechanical criteria}

In most cases, the pile design is initially based on structural requirements. However, additional factors are required for energy piles to quantify heat extraction and injection. The thermal expansion and contraction of the pile caused by heating and cooling should be checked in addition to the mechanical deformations and displacements under the service limit state. Moreover, thermally-induced forces applied to energy piles due to compression and tension should not reach the ultimate pile capacity. The distribution of stresses and strains induced by imposed thermal loads highly depends on the degree of freedom of the pile (DOF). It goes from maximum strains $\left(\varepsilon_{t h, \text { free }}=-\alpha_{E P} \Delta \mathrm{T}\right)$ for completely free piles (DOF $=1)$ to maximum internal stresses $\left(\sigma_{\text {th,fixed }}=\mathrm{E}_{E P} \alpha_{E P} \Delta \mathrm{T}\right)$ for perfectly restrained piles $(\mathrm{DOF}=0)[3,113]$. Therefore, Soga and Rui [60] suggested considering the maximum thermal-induced displacement of a free pile $\left(\omega_{\text {th,free }}=-\alpha_{E P} \Delta \mathrm{TL}\right)$ and the maximum thermal-induced stress $\left(\sigma_{\text {th,fixed }}\right)$ of a fully restrained pile as the primary design criteria to assess the serviceability and safety of the system. Bourne-Webb et al. [14] confirmed that $\sigma_{\text {th,fixed }}$ can be a conservative limit to check the thermal-induced stresses of energy piles most times. However, they pointed out that $\omega_{t h \text {,free }}$ cannot be a safe limit for checking the pile movements, especially for a large soil-to-pile thermal expansion ratio. Besides, it cannot be applied to a group of piles, where the group movement is much higher than that of an unrestrained single pile. Alternatively, Rotta Loria et al. [114] showed a critical behavior of energy piles in the cases of development of tensile stresses during cooling and evolution of mechanical cyclic degradation in sandy soils. In these cases, the consideration of $\sigma_{\text {th,fixed }}$ and $\omega_{\text {th,free }}$ as boundary criteria cannot be conservative. Therefore, complex thermo-mechanical analysis is needed to provide more realistic responses for single energy piles and pile groups under the ultimate and service limit states, addressing critical design issues.

Table 7. 4E-G evaluation criteria summary for GSHP system with energy piles

\begin{tabular}{|c|c|c|c|c|c|}
\hline Criterion & 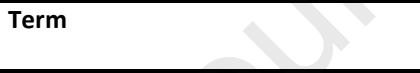 & Symbol & Equation & $\begin{array}{l}\text { Suitable } \\
\text { value }\end{array}$ & Reference \\
\hline \multirow[t]{5}{*}{ Energy } & Coefficient of performance & COP & $\frac{\text { Heat output }}{\text { Electrical energy input }}$ & $>3.5$ & \multirow[t]{5}{*}{ [90] [106-108] } \\
\hline & Heating Season Performance Factor & HSPF & $\frac{\text { Total seasonal heating output }}{\text { electrical energy input }}$ & $>6.8$ & \\
\hline & Seasonal Energy Efficiency Ratio & SEER & $\frac{\text { total seasonal cooling output }}{\text { electrical energy input }}$ & $8-10$ & \\
\hline & Energy Efficiency Ratio & EER & $\frac{\text { cooling capacity }}{\text { electrical energy input }}$ & $>10$ & \\
\hline & heat exchanger effectiveness & $\theta^{\mathrm{a}}$ & $\frac{T_{\text {in }}-T_{\text {out }}}{T_{\text {in }}-T_{g}}$ & & \\
\hline \multirow[t]{5}{*}{ Exergy } & Exergy efficiency & $\psi$ & $\frac{\text { exergy output }}{\text { total exergy input }}$ & & \multirow[t]{4}{*}{$\begin{array}{l}{[107,108,110,1} \\
11,115]\end{array}$} \\
\hline & & $\eta_{t h}$ & $1-\frac{\text { exergy destruction }}{\text { exergy input }}$ & & \\
\hline & Exergetic coefficient of performance & $\mathrm{COP}_{\mathrm{ex}}$ & $\frac{\text { exergy input }- \text { exergy output }}{\text { electrical energy input }}$ & & \\
\hline & Exergy loss & $\Delta \dot{\mathrm{E}}_{\mathrm{X}}$ & Exergy input - exergy output & & \\
\hline & entropy generation number & $\mathrm{Ns}^{\mathrm{a}}$ & $\begin{array}{l}\frac{S_{\text {gen }} T_{f, m}}{Q} \\
\Theta_{m}+\frac{A}{\pi R_{e}}+0.0195 \pi(1+\Phi) \frac{B}{\Theta_{m}} R^{11 / 4}\end{array}$ & & [116] \\
\hline \multirow[t]{7}{*}{ Economy } & Net present value & $N P V^{b}$ & $\sum_{\mathrm{t}=0}^{\mathrm{n}} \frac{\mathrm{Bt}}{(1+\mathrm{r})^{\mathrm{t}}}-\sum_{\mathrm{t}=0}^{\mathrm{n}} \frac{\mathrm{Ct}}{(1+\mathrm{r})^{\mathrm{t}}}$ & $>0$ & \multirow[t]{7}{*}[102,117-120]{} \\
\hline & & & (Annual savings) $\frac{(1+r)^{n}-1}{r(1+r)^{n}}-$ initial cost & & \\
\hline & & & $\sum_{\mathrm{t}=0}^{\mathrm{n}} \frac{\mathrm{C}_{\mathrm{t}}^{\mathrm{e}}-\mathrm{C}_{\mathrm{t}}^{\mathrm{a}}}{(1+\mathrm{r})^{\mathrm{t}}}$ & & \\
\hline & Internal rate of return & IRR & $\sum_{\mathrm{t}=0}^{\mathrm{n}} \frac{\mathrm{C}_{\mathrm{t}}^{\mathrm{e}}-\mathrm{C}_{\mathrm{t}}^{\mathrm{a}}}{(1+\mathrm{IRR})^{\mathrm{t}}}=0$ & & \\
\hline & Simple payback period & SPP & $\sum_{\mathrm{t}=0}^{\mathrm{SP} P} \mathrm{C}_{\mathrm{t}}^{\mathrm{e}}-\mathrm{C}_{\mathrm{t}}^{\mathrm{a}}=0$ & $2-10$ years & \\
\hline & Discounted payback period & DPP & $\sum_{\mathrm{t}=0}^{\mathrm{DPP}} \frac{\mathrm{C}_{\mathrm{t}}-\mathrm{C}_{\mathrm{t}}^{\mathrm{a}}}{(1+\mathrm{r})^{\mathrm{t}}}=0$ & & \\
\hline & Savings-to-investment ratio & $\operatorname{SIR}^{\mathrm{c}}$ & $\frac{\sum_{\mathrm{t}=0}^{\mathrm{n}} \frac{\mathrm{St}}{(1+\mathrm{r})^{\mathrm{t}}}}{\sum_{\mathrm{t}=0}^{\mathrm{n}} \frac{\mathrm{It}}{(1+\mathrm{r})^{\mathrm{t}}}}$ & $>1$ & \\
\hline
\end{tabular}




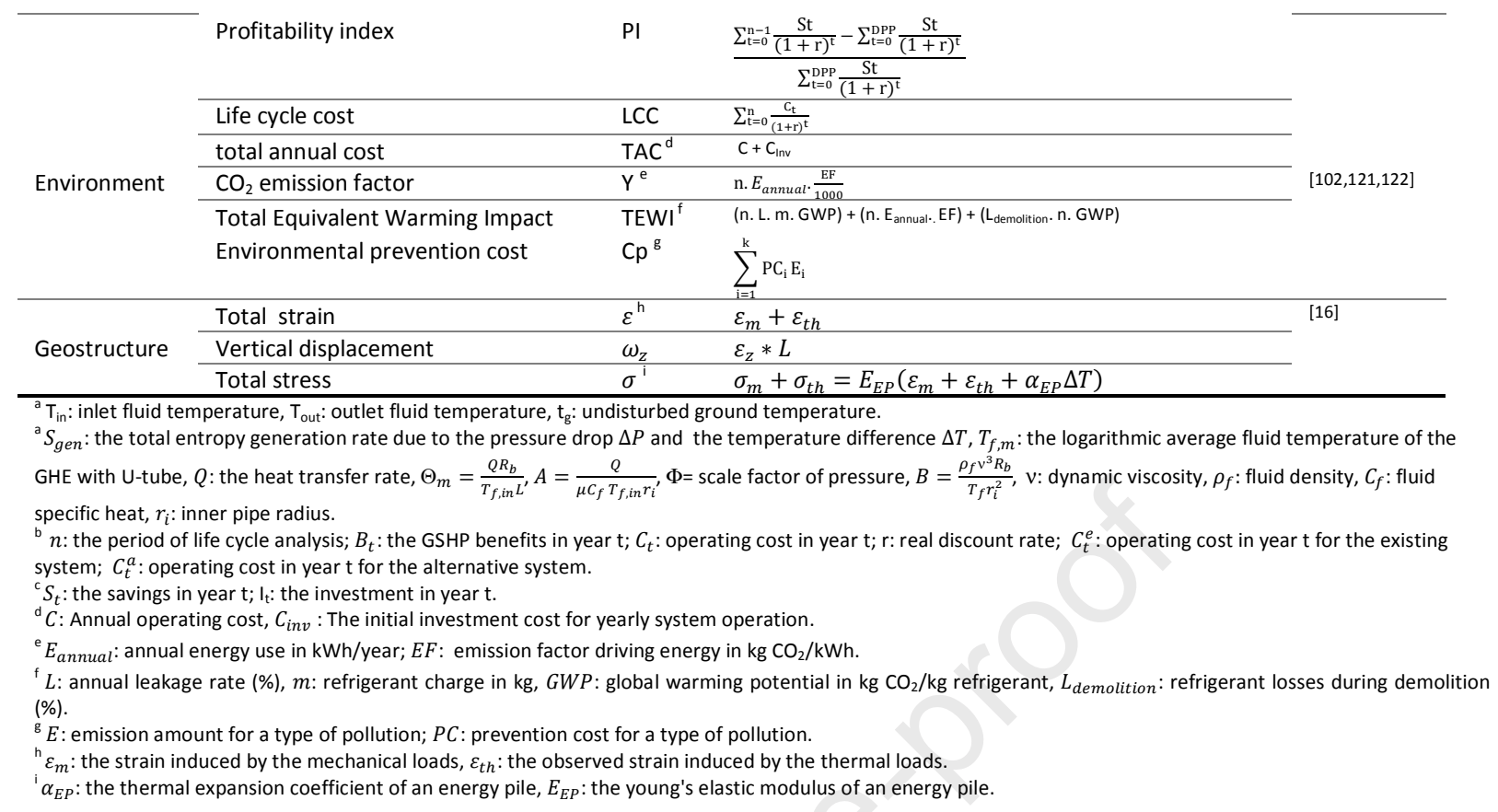

\section{Optimization of energy piles}

Optimization is vital for an optimized GSHP with energy piles as it can increase the thermal efficiency of the system and simultaneously decrease the system cost while maintaining system-induced stresses and strains within acceptable limits. All GSHP optimization studies associated with energy piles mainly focus on improving heat exchanger parameters to provide better thermal performance. However, the development of a complete strategy for the design optimization of these systems is still needed. Full coverage of existing optimization studies (which have mainly been published for borehole heat exchangers), including a review of objective functions, decision variables, design constraints, and optimization methods, is presented and discussed in this section.

\subsection{Objective function}

Generally, the design optimization of a thermal system is a process that involves improving system components and design parameters based on minimizing or maximizing single or multiple design objectives according to specific constraints [109]. For GSHP, it aims to optimize one or more objectives that are derived from the 4-E evaluation criteria described in Table 7.

\subsubsection{Single-objective optimization}

Many studies have developed a single-objective optimization in the geothermal field [123-125]. Major works include thermal and economic analysis to improve the design and operation of GSHP systems. For instance, Robert et al. [126] developed a new optimization design method of BHE to minimize the total cost of the GSHP system, including the initial costs of drilling, heat pump, excavation, and the cost of electricity. Li et Lai [127] established a single-objective optimization method to minimize entropy generation in a U-tube heat exchanger, and they found the optimal parameters of BHE. Huang et al. [128] developed an optimization methodology for BHE design to improve the thermodynamic 
performance of the GSHP system. The optimization strategy minimizes the entropy generation number (EGN), and it is based on defining the critical design parameters and design constraints as a first step, then devising the optimization solution, including the development of the objective function, the selection of the performance model and the optimization technique. The proposed method was validated using TRNSYS and achieved a 12.2\% reduction in EGN. However, the economic analysis of the borehole system based on optimized design parameters showed an increase in energy consumption of the heat pump compared to the base system design. The results reveal that optimizing one objective function of a system can deviate from the full effective design optimization.

\subsubsection{Multi-objective optimization}

Unlike single-objective optimization, multi-objective optimization considers multiple objective functions simultaneously. They overcome the shortcoming of single-objective design optimization techniques by providing comprehensive information on the impact of different objective functions on decision-making and helping to find appropriate optimized solutions [129]. According to Dinçer et al. [130], the multiobjective optimization problem is to find the appropriate design variable vector $\mathrm{X}\left\{x_{1}, x_{2}, \ldots, x_{n}\right\}$, which minimizes or maximizes the objective functions of $f_{1}(X), f_{2}(X), \ldots f_{N}(X)$, subjected to certain constraints. Few studies have been published on the multi-objective optimization of GSHP systems in the past years, with a significant focus on the thermo-economic approaches. Sayyaadi et al. [131] conducted a multiobjective design optimization study of a vertical ground-source heat pump system by examining thermodynamic and thermo-economic analysis simultaneously and considered eight decision variables for optimization. Huang et al. [116] applied a multi-objective design optimization for vertical GHE pipes to minimize both the cost of the system and the thermodynamic irreversibility induced by the entropy generation in-ground heat exchangers. The effectiveness of the proposed method was validated based on small-scale and large-scale case studies of GSHP systems implemented in Australia and China. Park et al. [132] presented their optimization study for borehole sizing based on thermal and economic aspects. The proposed method takes the life cycle cost and the entering fluid temperature to the heat pump as objective functions. The results showed a reduction in the total required length of BHE by $30 \%$. However, it remains only useful for the early design stage.

\subsubsection{Scalarization and Pareto solutions}

Two conventional approaches have been used to solve multi-objective optimization problems. The first one uses the weighted sum function to simplify the multiple objectives into a single-objective problem [133]. However, multi-objective optimization looks for tradeoffs between objectives that are in conflict rather than a single solution, considering the interferences between them [134,135]. The Pareto approach is the second solution used by most of the studies for multi-objective optimization. This tradeoff optimization consists of the development of a set of feasible non-dominated solutions called Pareto Front (or Pareto Frontier) to improve the objective function without ignoring another one [132]. The objective function values of the Pareto front refer to the set of all non-dominated optimal decision variables called the "Pareto optimal set" [136]. Figure 11 illustrates a typical example of Pareto solutions for a two-objective minimization problem where Pareto Front bounds non-dominated solutions. According to Cao et al. [137], Pareto-based algorithms benefit from the diversity of solutions. However, they exhibit problems of efficiency, such as slow convergence to the optimal front and low performance 
on the problems with many objectives. Li et al. [138] propose a bi-criterion evolution framework of Pareto and non-Pareto criteria to apply it in the evolutionary algorithms to overcome weaknesses in each evolution. The proposed framework was validated, experimentally, on 42 test problems with various characteristics. However, this new solution needs to be implemented and validated for GSHP systems.

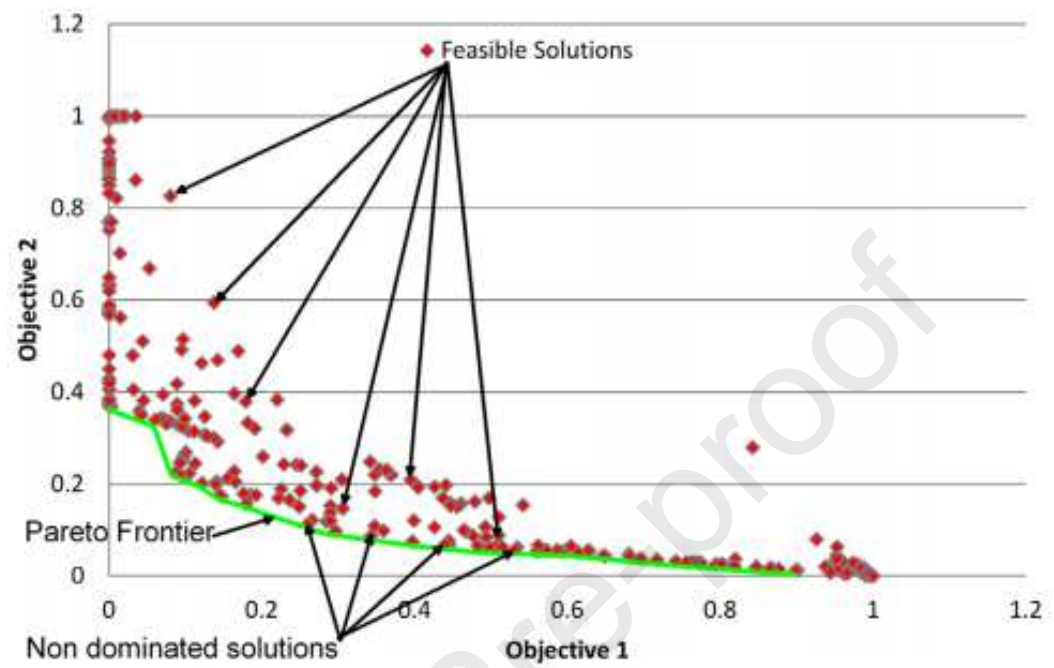

Figure 11. An example of Pareto Front for two-objective functions [134]

\subsubsection{Decision- making}

Analyzing a multi-objective optimization problem can result in a set of solutions based on the Pareto front, which can be a potential solution. However, selecting the ultimate optimal solution for all various objective functions at the same time needs decision-making [135]. Generally, decision-making is a problem-solving process that chooses the optimal solution among the available solutions of Pareto front based on the priority of each objective concerning other objectives for a specific design case [134]. The stability of the selected point and its sensitivity for input system parameters are also essential criteria for decision-makers [139]. GSHP optimization studies based on decision-making have received little attention in the literature. Therefore, further development in this area is recommended.

\subsection{Decision variables}

For a given optimization problem, the decision variables are the system parameters that affect the objective functions. So, analysis of these parameters is necessary to minimize or maximize these functions. For a GSHP system, various parameters affect its thermal optimization at different levels, including the building level, the heat pump level, and the GHE level. The latter is the most energy-saving part, as GHE has the minimum exergy efficiency and the maximum contribution to the installation cost of GSHP systems [110]. Some parameters can be changed and adjusted, while others are constrained either by installation conditions or by structural conditions. Therefore, identifying the decision variables that critically affect the performance of GSHP is vital for the optimization process. Experimental analysis can be used for optimization problems involving a limited number of parameters. However, in the case of GHE, numerical analysis is strongly recommended [140]. Many parametric studies have been published in the past years to investigate the most influential parameters of ground heat exchangers 
[140-145]. Fernández et al. [143] proved that the use of sensitivity analysis is effective for determining which parameters should be optimized. They also revealed a reduction in the number of iterations required for the optimization process by approximately $89 \%$. Huang et al. [128] carried out a global sensitivity analysis based on the Sobol method to determine the design variables of vertical heat exchangers.

The results showed a slight effect on the pipe thermal conductivity, the pipe shank distance, and the distance between the boreholes. Sivasakthivel et al. [140] observed that the heating load, the fluid inlet temperature, and the fluid flow rate have remarkable influences on COP and borehole thermal resistance. Cecinato and Loveridge [146] found that the number of GHE pipes is the most influential design parameter. For energy piles with spiral heat exchangers, the pitch size is the most critical factor affecting the heat transfer $[23,40,44]$. Batini et al. [13] studied the thermo-mechanical effects of many design parameters. They found that the configuration of tubes as $\mathrm{U}$-, double $\mathrm{U}$ - or $\mathrm{W}$-shape is the most important factor in both the thermal and mechanical performance of energy piles. They also found that the aspect ratio of the pile strongly affects the thermo-mechanical behavior. However, the mass flow rate of the circulating fluid affects only the thermal performance of the foundation. As well, the water antifreeze mixtures did not have a noticeable effect in this context. The design parameters used in the reviewed studies to optimize the vertical heat exchangers have thermal effects, not structural parameters (Table 8). Jelušič and Žlender [147] fill this gap in their new study to optimize the cost of energy piles. The vertical loads, the number of reinforcing steel bars, and the young soil modulus are the decision variables studied. However, wide-ranging research is still needed to detect decision variables by studying more thermal and structural parameters.

Table 8. A summary of the decision variables detected in some previous studies.

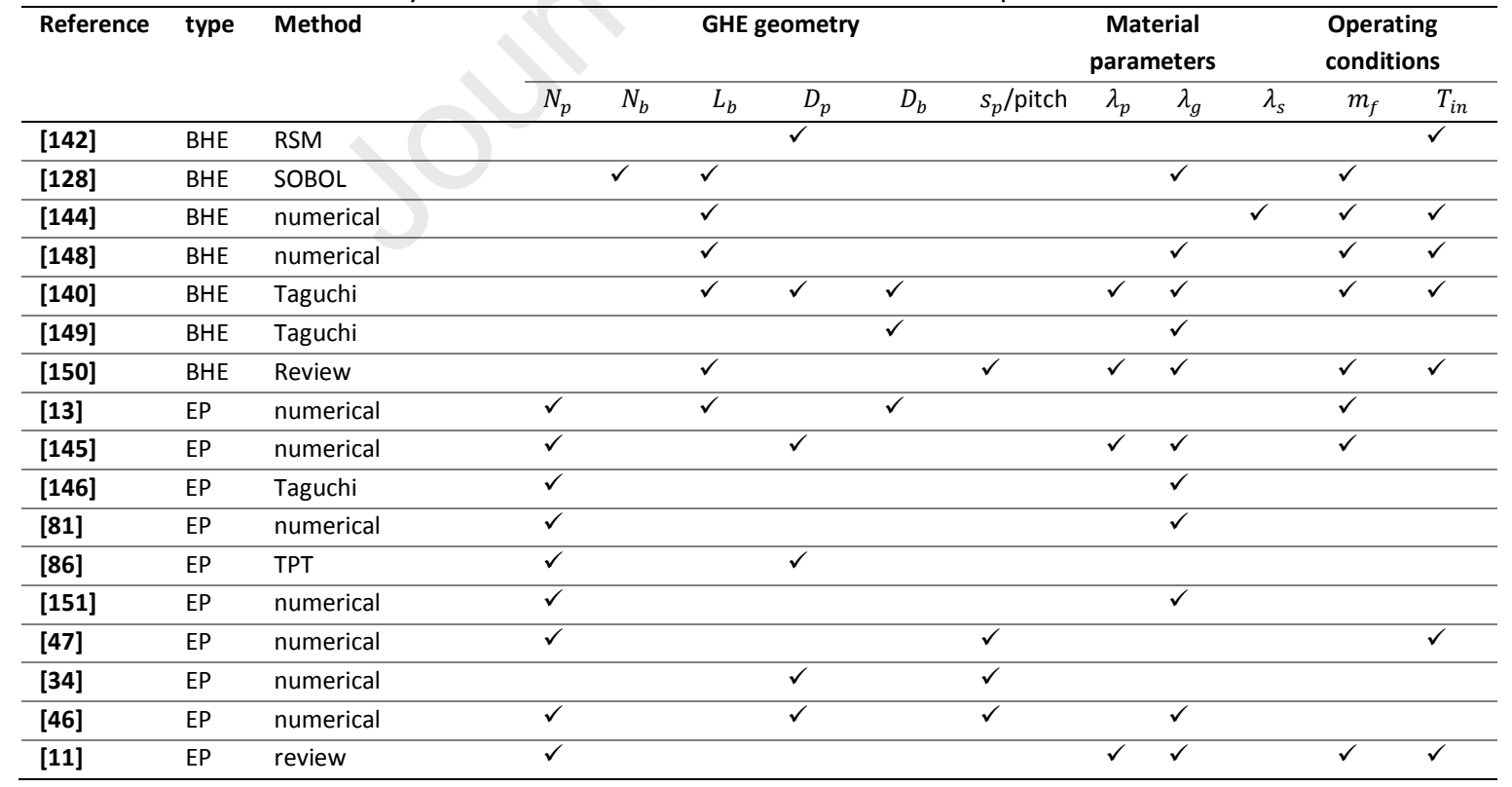




\subsection{Constraints}

In optimization problems, design variables do not take arbitrary values but are restricted by some specified boundaries and conditions called design constraints [3]. Constraints for GSHP systems can be classified into levels, such as geometrical constraints related to the configuration and geometry of GHE, constraints associated with the material properties and the operational parameters of the system, and temperature constraints $[90,128]$. Typical thermal constraints applied to the design of ground heat exchangers can be reported in the literature. Some guidelines highlighted the effect of fluid freezing on the performance of energy piles. They, therefore, recommended maintaining the fluid temperature above zero with a safety margin of $2^{\circ} \mathrm{C}[5,6]$. They also suggested that this temperature does not exceed $40^{\circ} \mathrm{C}$ because of the negative effect of high temperature on the efficiency of the heat pump [91]. However, unlike boreholes, energy piles are primarily designed to meet structural purposes and, therefore, parametric optimization must be controlled to avoid exceeding the limits of the structure. The stresses, strains, and the displacement of the pile should be below the allowable limits to avoid system failure resulting from temperature changes $[91,147]$. Determining the pile end conditions that can be unrestrained, fully restrained, or partially restrained also plays an essential role in the evolution of the foundation constraints. Therefore, mechanical restrictions can be a key target that should be introduced in the optimization study of energy piles.

\subsection{Optimization methods}

Various computational methods have been used to optimize energy systems. The selection of a technique depends on the type of problem being faced, the computational cost for models, and the time available for a project [134], [141]. Therefore, applying the appropriate one can significantly decrease the simulation run time and provides accurate optimum results. Brief details of the optimization algorithms used to optimize ground heat exchangers are listed below, including the genetic algorithm, other derivative-free optimization methods, and hybrid algorithms where more than one optimization algorithm is integrated (Table 9).

\subsubsection{Genetic algorithm (GA)}

The genetic algorithm (GA) is the most widely used optimization method in energy systems. It relies on evolutionary techniques combining selection, crossover, and mutation operators to find the best solution to a problem. The process begins with a population of randomly generated candidate solutions called individuals, where each individual is evaluated. During each generation, GA selects the right individuals who are adjusted through mutation to form a new population. The process is repeated until the algorithm reaches the maximum number of generations or the satisfactory level of fitness for the population. In the end, the algorithm converges to the best individual, which represents the optimal solution to the given problem [152]. Genetic algorithms have many advantages for finding optimal values [153]. They are easy to understand, simple to implement, and less sensitive to initialization [61]. Compared to traditional optimization methods, GAs have less computing time, good convergence, and higher robustness with no need for differentiable or continuous search space. However, they can have some disadvantages, such as long convergence time for large and complex problems, problems of inaccuracy, and the possibility of proposing inaccurate solutions [154]. Several studies have used genetic algorithms for the optimization of GSHP systems with vertical GHE pipes [128,131]. Zeng et al. [155] 
used the GA algorithm with 500 generations and 40 individuals. Sanaye and Niroomand [156] selected the GA characteristics as 1000 generations, 100 individuals in each population, with a $10 \%$ mutation probability. However, Park et al. [132] only used ten generations and 40 individuals for their multiobjective optimization study. These small values can be attributed to the limited number of variables designed in the study. Pu et al. [157] presented an alternative method of multi-objective optimization (MOGA) based on the non-dominate sorting genetic algorithm (NSGA-II). The GSHP system showed higher performance with the optimized parameters of the MOGA method compared to that of the screening method.

\subsubsection{Artificial Neural Network (ANN)}

Artificial Neural Network (ANN) is a non-linear method that uses brain processing as a basis for developing algorithms used to model complex patterns and optimization problems. It acts as a black box that uses training data to link processing elements, called artificial neurons, to find the relationship between the input and output without requiring detailed information about the system [158]. ANN can handle a large number of data sets. It can implicitly detect non-linear, distributed, and parallel interactions between variables, even for complex problems. Afram et al. [154] proposed using ANNbased heuristic algorithms for optimization where the application of linear algorithms is unfeasible. Their proposal consists of transforming the objective functions into a new function by training neural networks, which allows the generation of a polynomial equation to solve the optimization problem. In the geothermal field, some authors have used the neural network to assess the performance of GSHP systems $[148,158-160]$. However, it is still not applied as a method of optimization for ground heat exchangers.

\subsubsection{The Nelder-Mead method (NM)}

Nelder-Mead (NM) is a numerical optimization method used to find the optimum solution for functions of $\mathrm{N}$ variables by comparing function values at the three vertices of a triangle. The process generates a series of triangles with different dimensions in which the worst vertex that has the most significant function values is rejected and replaced with a new vertex. The process continues as long as function values are reduced at the vertices until the minimum is found. This method can represent good convergence due to its rapid calculation time. However, in many cases, it fails to obtain the optimal values due to the non-equality constraints of design parameters [134]. Sanaye and Niroomand [156] overcome this shortcoming by modifying the algorithm to enable it to work with inequality constraints. Then, they used the modified NM to obtain the optimum design parameters of a vertical ground coupled heat pump system. The optimal parameters obtained from NM were compared with those obtained from the genetic algorithm, and the results found a good agreement between the two methods.

\subsubsection{Mixed-integer Non-linear programming (MINLP)}

Mixed-integer non-linear programming (MINLP) is a mathematical optimization methodology that addresses non-linear problems in objective functions and constraints [135]. Decision variables are constrained in this method either by integers or non-integer ranges. One study on the use of MINLP to optimize GSHP systems was detected. Retkowski and Thöming [161] used the Generalized Reduced 
Gradient algorithm (GRG2) based on MINLP to optimize the main design parameters of a vertical ground heat exchanger. The total annual costs and the COP are both objective functions included in the model for detecting economic and thermodynamic aspects. They found that the GRG2 approach has higher stability and less computing time than evolutionary algorithms (EA). An overall annual cost improvement of over $10 \%$ was also detected using MINLP.

\subsubsection{Hooke-Jeeves pattern search algorithm (HJ)}

The pattern search algorithm developed by Hooke and Jeeves is a type of derivative-free optimization method that can optimize non-continuous and non-differentiable functions. It finds the best match by tracking the behavior of the objective function using a series of exploratory moves as a point-to-point transition without starting from scratch at each new point [134]. Pattern search algorithm benefits from low computational time compared to other algorithms. Khan and Spitler [162] applied the Hooke-Jeeves search algorithm to optimize the design of a GSHP system using the GenOpt tool. Zhang et al. [163] also used it for this purpose. They found that the optimization methodology using $\mathrm{HJ}$ can suitably provide an appropriate tool to achieve the best BHE design parameters in GSHP. However, it is still less effective than other derivative methods. A comparison of the Hooke-Jeeves algorithm with the genetic algorithm showed better performance for GA in all comparison cases [135]. Nevertheless, Machairas et al. [37] pointed to the higher robustness of $\mathrm{HJ}$ compared to noisy functions when analytical derivatives are not available; or when finite difference approximations for the gradient are unreliable.

\subsubsection{Taguchi's method}

The Taguchi method is a new technique of optimization. It is based on the design of experiments to determine the best combination of parameters [140]. This method uses a set of orthogonal arrays to arrange the variable parameters at different levels with a minimum number of experiments. The signalto-noise ratio $(\mathrm{S} / \mathrm{N})$ is evaluated during the process for all parameter levels, where the maximum $\mathrm{S} / \mathrm{N}$ value indicates the optimal level. Taguchi is one of the best tools to improve an objective, especially in product development and industrial engineering fields [164]. However, its disadvantage comes from its limitation to improve multi-objective functions [140]. A limited number of studies on Taguchi's method for improving GSHP design parameters have been reported [140,149,165].

Table 9. Summary of studies focused on the optimization of vertical heat exchanger design.

\begin{tabular}{|c|c|c|c|c|c|c|c|}
\hline \multirow[t]{2}{*}{ Reference } & \multirow{2}{*}{\multicolumn{2}{|c|}{ Objective function }} & \multirow{2}{*}{$\begin{array}{l}\text { Design } \\
\text { variables }\end{array}$} & \multicolumn{3}{|c|}{ Constraints } & \multirow{2}{*}{$\begin{array}{l}\text { Optimization method/ } \\
\text { software }\end{array}$} \\
\hline & & & & Parameter & Min & Max & \\
\hline \multirow{5}{*}{$\begin{array}{l}\text { Sanaye and } \\
\text { Niroomand } \\
{\left[_{[156]^{a}}\right.}\end{array}$} & \multirow[t]{5}{*}{ Single } & \multirow[t]{5}{*}{ TAC } & $D_{p}$ & $T_{\text {in }}$ (heating mode) & $0^{\circ} \mathrm{C}$ & & \multirow[t]{5}{*}{ NM, GA/ optiGA tool } \\
\hline & & & $T_{\text {in }}$ & $T_{\text {evap }}$ (heating mode) & $-50^{\circ} \mathrm{C}$ & & \\
\hline & & & $T_{\text {out }}$ & $T_{\text {evap }}$ (cooling mode) & $-50^{\circ} \mathrm{C}$ & & \\
\hline & & & $T_{\text {evap }}$ & $T_{w i}-T_{\text {evap }}$ & $10^{\circ} \mathrm{C}$ & & \\
\hline & & & $T_{\text {cond }}$ & $T_{\text {cond }}-T_{w i}$ & $10^{\circ} \mathrm{C}$ & & \\
\hline \multirow[t]{4}{*}{$\begin{array}{l}\text { Khalajzadeh } \\
\text { et al. [142] }\end{array}$} & \multirow[t]{4}{*}{ multiple } & $\eta$ & $L_{b}$ & $\frac{L_{b}}{D_{b}}$ & 120 & 600 & $\begin{array}{l}\text {-/Design-Expert } \\
\text { software }\end{array}$ \\
\hline & & $\theta$ & $D_{p}$ & $\frac{D_{p}}{D_{b}}$ & 0.2 & 0.3334 & \\
\hline & & & $T_{\text {in }}$ & $\frac{T_{i n}}{T_{g}}$ & 1.75 & 2.5 & \\
\hline & & & $\operatorname{Re}$ & $\operatorname{Re}$ & 3200 & 9600 & \\
\hline \multirow{2}{*}{$\begin{array}{l}\text { Li and Lai } \\
\text { [127] }\end{array}$} & \multirow[t]{2}{*}{ Single } & \multirow[t]{2}{*}{ EGN } & $L_{b}$ & - & & & \multirow[t]{2}{*}{ Calculation based/- } \\
\hline & & & $\operatorname{Re}$ & & & & \\
\hline Bayer et al. & Single & Change in & $N_{b}$ & - & & & linear programming /- \\
\hline
\end{tabular}




\begin{tabular}{|c|c|c|c|c|c|c|c|}
\hline [124] & & $\begin{array}{l}\text { ground } \\
\text { temperature }\end{array}$ & $\begin{array}{l}s_{b} \\
\text { Thermal } \\
\text { loads }\end{array}$ & & & & \\
\hline \multirow{4}{*}{$\begin{array}{l}\text { Robert and } \\
\text { Gosselin } \\
{[126]^{b}}\end{array}$} & \multirow[t]{4}{*}{ Single } & \multirow[t]{4}{*}{ LCC } & $L_{b}$ & $L_{b}$ & $45 \mathrm{~m}$ & $105 \mathrm{~m}$ & \multirow{4}{*}{$\begin{array}{l}\text { Fast Fourier Transform/ } \\
\text { MATLAB }\end{array}$} \\
\hline & & & $s_{b}$ & $s_{b}$ & $3 m$ & $8 \mathrm{~m}$ & \\
\hline & & & $N_{b}$ & $P$ & $60 \%$ & $90 \%$ & \\
\hline & & & size of HP & $\frac{Q_{\text {field-peak }}}{N_{b} L_{b}}$ & 30 & 130 & \\
\hline \multirow{9}{*}{$\begin{array}{l}\text { Huang et al. } \\
\text { [128] }\end{array}$} & \multirow[t]{9}{*}{ Single } & \multirow[t]{9}{*}{ EGN } & $N_{b}$ & $N_{b}$ & 1 & & \multirow[t]{9}{*}{ GA/ MATLAB } \\
\hline & & & $L_{b}$ & $L_{b}$ & $50 \mathrm{~m}$ & $200 \mathrm{~m}$ & \\
\hline & & & $r_{b}$ & $r_{b}$ & $0.0325 \mathrm{~m}$ & $0.1 \mathrm{~m}$ & \\
\hline & & & $r_{p}$ & $r_{p}$ & $0.012 \mathrm{~m}$ & $0.022 \mathrm{~m}$ & \\
\hline & & & $m_{f}$ & $m_{f}$ & $0.1 \mathrm{~kg} / \mathrm{s}$ & $1 \mathrm{~kg} / \mathrm{s}$ & \\
\hline & & & & $\lambda_{g}$ & $0.5 \mathrm{w} / \mathrm{mk}$ & $2.5 \mathrm{w} / \mathrm{mk}$ & \\
\hline & & & & $\lambda_{p}$ & $0.2 \mathrm{w} / \mathrm{mk}$ & $0.6 \mathrm{w} / \mathrm{mk}$ & \\
\hline & & & & $\lambda_{s}$ & $0.5 \mathrm{w} / \mathrm{mk}$ & $2.5 \mathrm{w} / \mathrm{mk}$ & \\
\hline & & & & Initial soil temperature & $10^{\circ} \mathrm{C}$ & $20^{\circ} \mathrm{C}$ & \\
\hline \multirow{5}{*}{$\begin{array}{l}\text { Retkowski } \\
\text { and } \\
\text { Thöming } \\
\text { [161] }\end{array}$} & \multirow[t]{5}{*}{ Single } & TAC & $N_{b}$ & \multirow[t]{5}{*}{-} & & 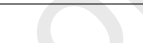 & \multirow[t]{5}{*}{ MILP/ Excel } \\
\hline & & $\overline{C O P}$ & $L_{b}$ & & & & \\
\hline & & & $m_{f}$ & & & & \\
\hline & & & Type of HP & & & & \\
\hline & & & $\begin{array}{l}\text { Number of } \\
\text { HP }\end{array}$ & & & & \\
\hline \multirow{7}{*}{$\begin{array}{l}\text { Sivasakthivel } \\
\text { et al. [140] }\end{array}$} & \multirow[t]{7}{*}{ Single } & $L_{b}$ & $r_{b}$ & \multirow[t]{7}{*}{-} & & & \multirow{7}{*}{$\begin{array}{l}\text { Taguchi method, utility } \\
\text { concept/ - }\end{array}$} \\
\hline & & COP & $r_{p}$ & & & & \\
\hline & & $R_{b}$ & $s_{p}$ & & & & \\
\hline & & & $\lambda_{g}$ & & & & \\
\hline & & & $\lambda_{p}$ & & & & \\
\hline & & & $m_{f}$ & & & & \\
\hline & & & $\begin{array}{l}T_{\text {in }} \\
\text { Heating load }\end{array}$ & & & & \\
\hline \multirow{4}{*}{$\begin{array}{l}\text { GAMAGE et } \\
\text { al. }[123]^{c}\end{array}$} & \multirow[t]{4}{*}{ Single } & \multirow[t]{4}{*}{ NPV } & $N_{b}$ & $N_{b}$ & 4 & 144 & Monte-Carlo model/- \\
\hline & & & $L_{b}$ & DR & 1 & 9 & \\
\hline & & & $s_{b}$ & $\frac{s_{b}}{L_{b}}$ & 0.05 & 1 & \\
\hline & & & $\sqrt{3}$ & $\ln \frac{t}{t s}$ & -2 & 3 & \\
\hline Huang et al. & Multiple & EGN & $N_{b}$ & $N_{b}$ & 1 & & GA/ MATLAB \\
\hline [116] & & Initial cost & $L_{b}$ & $L_{b}$ & $50 \mathrm{~m}$ & $200 \mathrm{~m}$ & \\
\hline & & & $r_{b}$ & $r_{b}$ & $0.0325 \mathrm{~m}$ & $0.1 \mathrm{~m}$ & \\
\hline & & & $r_{p}$ & $r_{p}$ & $0.012 \mathrm{~m}$ & $0.022 \mathrm{~m}$ & \\
\hline & & & $m_{f}$ & $m_{f}$ & $0.1 \mathrm{~kg} / \mathrm{s}$ & $1 \mathrm{~kg} / \mathrm{s}$ & \\
\hline & & & & $\lambda_{g}$ & $0.5 \mathrm{w} / \mathrm{mk}$ & $2.5 \mathrm{w} / \mathrm{mk}$ & \\
\hline & & & & $\lambda_{p}$ & $0.2 \mathrm{w} / \mathrm{mk}$ & $0.6 \mathrm{w} / \mathrm{mk}$ & \\
\hline & & & & $\lambda_{s}$ & $0.5 \mathrm{w} / \mathrm{mk}$ & $2.5 \mathrm{w} / \mathrm{mk}$ & \\
\hline & & & & Initial soil temperature & $10^{\circ} \mathrm{C}$ & $20^{\circ} \mathrm{C}$ & \\
\hline Zhang et al. & Single & Temperature & $L_{b}$ & $L_{b}$ & $45 \mathrm{~m}$ & $105 \mathrm{~m}$ & $\mathrm{HJ} /-$ \\
\hline [163] & & function & $s_{b}$ & $s_{b}$ & $3 \mathrm{~m}$ & $8 \mathrm{~m}$ & \\
\hline & & & $N_{b}$ & $N_{b} L_{b}$ & $\frac{Q_{\text {field-peak }}}{130}$ & $\frac{Q_{\text {field-peak }}}{30}$ & \\
\hline Park et al. & multiple & LCC & $L_{b}$ & $L_{b}$ & $85 \mathrm{~m}$ & $200 \mathrm{~m}$ & NSGA-II/ Multiopt2 \\
\hline [132] & & Temperature & $s_{b}$ & $s_{b}$ & $4 m$ & $7 m$ & \\
\hline & & function & $N_{b}$ & $N_{b}$ & 35 & 45 & \\
\hline Ma and Xia & Single & Energy & $T_{\text {out }}$ & $T_{\text {out }}$ (cooling mode) & $6^{\circ} \mathrm{C}$ & & -/ model-based \\
\hline & & consumption & & $T_{\text {out }}$ (heating mode) & $20^{\circ} \mathrm{C}$ & & approach \\
\hline Pu et al. & Multiple & EGN & $\mathrm{D}_{\mathrm{b}}$ & $\mathrm{D}_{\mathrm{p}}$ & 1 & 4 & MOGA/ TRNSYS \\
\hline$[157]^{d}$ & & & & $\overline{\mathrm{D}_{\mathrm{b}}}$ & $\overline{15}$ & $\overline{15}$ & \\
\hline & & IEF & $\mathrm{D}_{\mathrm{p}}$ & $\frac{S_{p}}{n}$ & $\underline{1}$ & $\underline{1}$ & \\
\hline & & & & $\overline{\mathrm{D}_{\mathrm{b}}}$ & $\overline{6}$ & $\overline{3}$ & \\
\hline & & & $\mathrm{s}_{\mathrm{p}}$ & $\frac{\mathrm{T}_{\text {in }}}{\mathrm{T}_{\mathrm{g}}}$ & 1.75 & 2.5 & \\
\hline & & & $\mathrm{m}_{\mathrm{f}}$ & $\operatorname{Re}$ & 994 & 39769 & \\
\hline
\end{tabular}


${ }^{a} \mathrm{~T}_{\mathrm{wi}}$ : the inlet temperature to the heat pump from the building; $\mathrm{T}_{\text {cond }}$ : condensation temperature; $\mathrm{T}_{\text {evap }}$ : evaporation temperature.

${ }^{\mathrm{b}} P$ : Percentage of the building peak load.

${ }^{c} D R$ : distribution ratio= the number of boreholes in the longer direction over the number of boreholes in the other direction, $\mathrm{t}_{\mathrm{s}}$ : the characteristic time $L^{2} / 9 \alpha$ where $\alpha$ : the thermal diffusivity of soil.

${ }^{\mathrm{d}} I E F$ : integrated evaluation factor, $\mathrm{v}$ : inlet flow velocity.

\subsection{Developed optimization scheme}

Figure 12 summarizes the steps of the proposed design strategy for energy piles basing on a global optimization approach. 


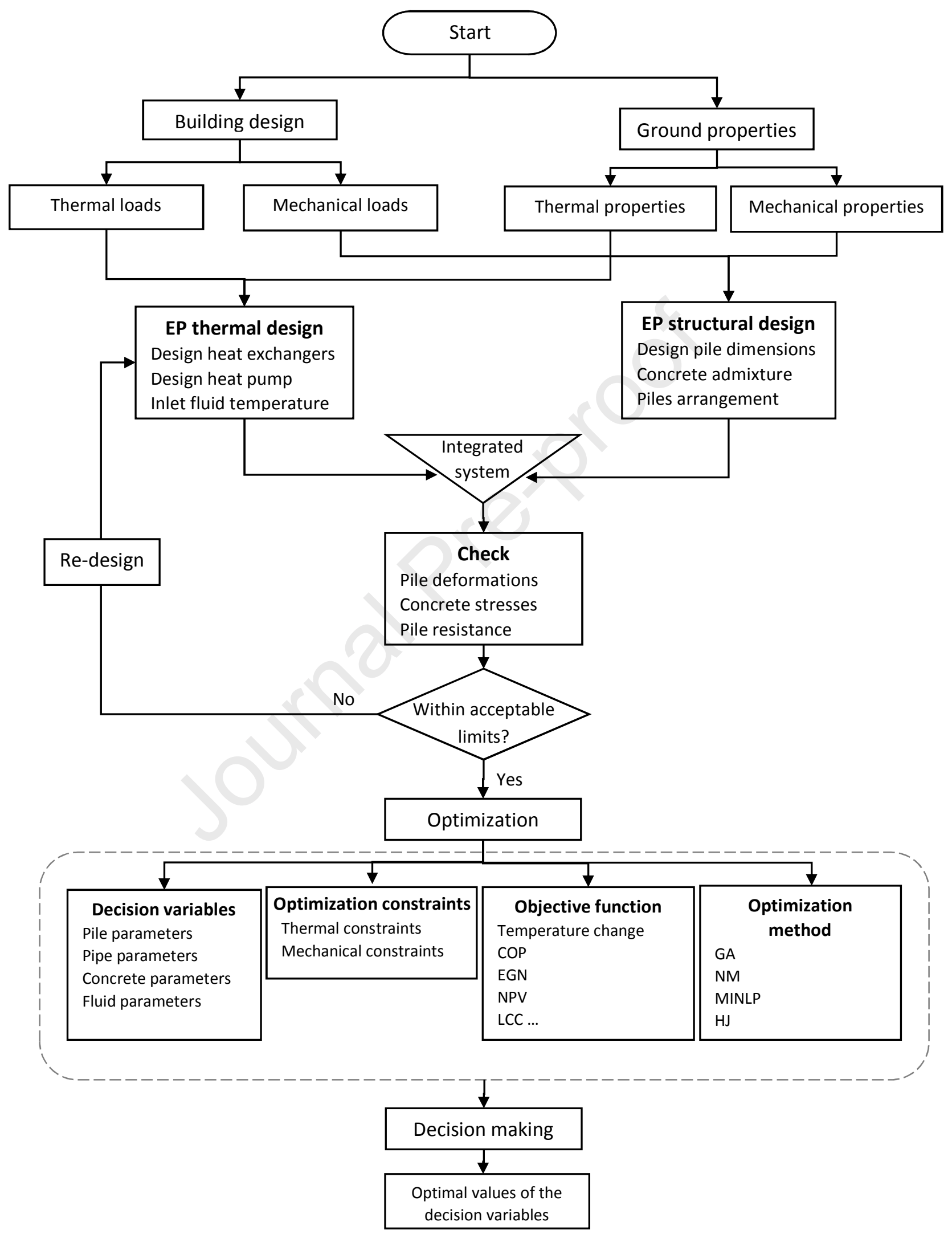

Figure 12. The developed optimization approach for energy piles design 


\section{Conclusions}

While the thermal analysis of borehole heat exchangers is specified, and their design and dimensions can be controlled to meet thermal requirements and establish the optimal system, the design of energy piles is a complex matter derived from the interaction between thermal and mechanical loads. A comprehensive understanding of all design aspects of energy piles is required, and developing an optimization strategy is still needed. This review has the purpose of filling the gaps regarding these aspects. It represents the current state of knowledge about the analysis methods used for energy piles, investigates the thermal and thermo-mechanical behaviors of these systems, summarizes the $4 \mathrm{E}-\mathrm{G}$ evaluation criteria, and presents an overview of optimization methods that can be applied to such systems. Finally, it proposes a comprehensive strategy for design and optimization of energy piles, considering thermal, economic, environmental, and mechanical perspectives. Some important conclusions can be stated:

- Numerical modeling is recommended to simulate energy piles due to their high accuracy in detecting the thermal and thermo-mechanical response of these systems. However, experimental and numerical benchmarking validations are necessary for the assumptions and simplifications used in the literature to reduce the high computational time taken by a full numerical model. The heat flow should also be addressed to consider the actual thermal behavior of energy piles.

- The thermally-induced changes of stresses and strains in energy piles depend strongly on the pile fixity and can reach critical values if the restraint conditions are not correctly defined. Therefore, integrating the real restraint conditions into the modeling is still necessary to detect the actual design of energy piles at different restraint levels. They also depend on the percentage of mechanical loads applied to the foundation where irreversible settlement can occur for axial mechanical loads exceeding $30 \%-40 \%$ of the ultimate resistance.

- The maximum internal stresses of perfectly restrained piles can be a conservative limit to check the thermally-induced stresses of a single energy pile. However, the maximum displacement of completely free piles is not a safe constraint to check pile movements, especially where the soilto-pile thermal expansion ratio is large. For a group of piles, the use of these limits is not useful. A complex thermo-mechanical analysis is therefore required to provide safe criterion constraints for single energy pile and pile groups under the ultimate and service limit states.

- The response of a group of energy piles depends on various variables influencing the interaction between piles, such as pile spacing, the soil-to-pile thermal expansion coefficient ratio, and the pile stiffness. However, more information is still needed to determine the effect of these variables on the behavior of both active and non-active piles. Besides, detecting the best positions and number of active energy piles in a foundation is an important target that should be investigated.

- The heterogeneity of the concrete mixture can have a sensitive effect on the thermal cracks induced in cement-based materials due to the contraction and expansion of energy piles. A mesoscopic approach is therefore recommended integrating the thermally-induced cracks of concrete into modeling to study their effects on the real mechanical behavior and the long-term thermal performance of energy piles. 
- The efficiency of heat transfer in an energy pile depends on the design parameters concerning the characteristics of the pile, pipe, concrete, fluid, and ground. The configuration of heat exchanger pipes is found to be the most influential parameter. Adding thermally enhanced materials to the concrete mix can also improve the thermal performance of concrete by $40 \%$. However, it should be accompanied by structural and economic feasibility studies to maintain the typical compressive strength of concrete and to ensure the cost-effectiveness of the structure.

- To create an optimal geometry for heat exchangers in an energy pile with U-/W- or spiral configuration, it is recommended to set a minimum shank spacing/pitch size of $250 \mathrm{~mm}$ to prevent thermal interactions between the adjacent pipe loops. It is also recommended to attach the GHE pipes to the pile reinforcement cage, which minimizes the high thermal resistance of the concrete cover.

- The development of an optimal energy pile system involves complex analyzes. It comprises the selection of objective functions, the detection of decision variables and system design constraints, then the best optimization method. GA proves to be the most popular optimization method, but MINLP proves to be more efficient, more stable, and faster than GA.

- The number of heat exchanger pipes, the mass flow rate, the thermal conductivity of grouting material, and the inlet fluid temperature are the most common decision variables reviewed in previous studies. However, a wide-ranging study on structural parameters is also suggested.

- Multi-objective optimization of energy piles, including the 4E-G assessments (energy, exergy, economy, environment, and geo-structure) can be a vital objective for future studies.

\section{Acknowledgments}

The authors would like to thank the Association of Specialization and Scientific Guidance (ASSG), the Agence Universitaire de la Francophonie (AUF), the National Council for Scientific Research of Lebanon (CNRS-L), and the Erasmus+ Programme for their financial support.

\section{References}

[1] Sbci, U.N.E.P. Buildings and climate change: Summary for decision-makers. United Nations Environmental Programme, Sustainable Buildings and Climate Initiative, Paris 2009:1-62.

[2] Adam D, Markiewicz R. Energy from earth-coupled structures, foundations, tunnels and sewers. Géotechnique 2009;59:229-36. https://doi.org/10.1680/geot.2009.59.3.229.

[3] Lyesse Laloui, Di Donna A, editors. Energy geostructures: innovation in underground engineering. London: John Wiley \& Sons Inc; 2013.

[4] Laloui L, Di Donna A. Understanding the behaviour of energy geo-structures. Proceedings of the Institution of Civil Engineers - Civil Engineering 2011;164:184-91. https://doi.org/10.1680/cien.2011.164.4.184.

[5] Bourne-Webb P, Burlon S, Javed S, Kürten S, Loveridge F. Analysis and design methods for energy geostructures. Renewable and Sustainable Energy Reviews 2016;65:402-19. https://doi.org/10.1016/j.rser.2016.06.046.

[6] Fadejev J, Simson R, Kurnitski J, Haghighat F. A review on energy piles design, sizing and modelling. Energy 2017;122:390-407. https://doi.org/10.1016/j.energy.2017.01.097. 
[7] Zagorscak R, Thomas HR. A review on performance of energy piles and effects on surrounding ground. Inzenjerstvo Okolisa (Environmental Engineering) 2016;3:33-45.

[8] de Moel M, Bach PM, Bouazza A, Singh RM, Sun JO. Technological advances and applications of geothermal energy pile foundations and their feasibility in Australia. Renewable and Sustainable Energy Reviews 2010;14:2683-96. https://doi.org/10.1016/j.rser.2010.07.027.

[9] Loveridge F, Powrie W. Pile heat exchangers: thermal behaviour and interactions. Proceedings of the Institution of Civil Engineers - Geotechnical Engineering 2013;166:178-96. https://doi.org/10.1680/geng.11.00042.

[10] Raouf AMI, Raouf MIN, Abuel-Naga H, Nasser AG. Energy piles: current state of knowledge and design challenges. Environmental Geotechnics 2015;2:195-210. https://doi.org/10.1680/envgeo.13.00019.

[11] Faizal M, Bouazza A, Singh RM. Heat transfer enhancement of geothermal energy piles. Renewable and Sustainable Energy Reviews 2016;57:16-33. https://doi.org/10.1016/j.rser.2015.12.065.

[12] Noorollahi Y, Saeidi R, Mohammadi M, Amiri A, Hosseinzadeh M. The effects of ground heat exchanger parameters changes on geothermal heat pump performance - A review. Applied Thermal Engineering 2018;129:1645-58. https://doi.org/10.1016/j.applthermaleng.2017.10.111.

[13] Batini N, Rotta Loria AF, Conti P, Testi D, Grassi W, Laloui L. Energy and geotechnical behaviour of energy piles for different design solutions. Applied Thermal Engineering 2015;86:199-213. https://doi.org/10.1016/j.applthermaleng.2015.04.050.

[14] Bourne-Webb PJ, Bodas Freitas TM, Freitas Assunção RM. A review of pile-soil interactions in isolated, thermally-activated piles. Computers and Geotechnics 2019;108:61-74. https://doi.org/10.1016/j.compgeo.2018.12.008.

[15] Sani AK, Singh RM, Amis T, Cavarretta I. A review on the performance of geothermal energy pile foundation, its design process and applications. Renewable and Sustainable Energy Reviews 2019;106:54-78. https://doi.org/10.1016/j.rser.2019.02.008.

[16] Lyesse Laloui, Alessandro F. Rotta Loria. Analysis and Design of Energy Geostructures. Elsevier; 2020. https://doi.org/10.1016/B978-0-12-816223-1.00017-5.

[17] Park S, Lee S, Oh K, Kim D, Choi H. Engineering chart for thermal performance of cast-in-place energy pile considering thermal resistance. Applied Thermal Engineering 2018;130:899-921. https://doi.org/10.1016/j.applthermaleng.2017.11.065.

[18] Lei F, Hu P, Huang X. Hybrid analytical model for composite heat transfer in a spiral pile ground heat exchanger. Applied Thermal Engineering 2018;137:555-66. https://doi.org/10.1016/j.applthermaleng.2018.04.019.

[19] Cui Y, Zhu J. Year-round performance assessment of a ground source heat pump with multiple energy piles. Energy and Buildings 2018;158:509-24. https://doi.org/10.1016/j.enbuild.2017.10.033.

[20] Rui Y, Garber D, Yin M. Modelling ground source heat pump system by an integrated simulation programme. Applied Thermal Engineering 2018;134:450-9. https://doi.org/10.1016/j.applthermaleng.2018.01.123.

[21] Cui Y, Zhu J. CFD assessment of multiple energy piles for ground source heat pump in heating mode. Applied Thermal Engineering 2018;139:99-112. https://doi.org/10.1016/j.applthermaleng.2018.04.073.

[22] Ghasemi-Fare O, Basu P. Influences of ground saturation and thermal boundary condition on energy harvesting using geothermal piles. Energy and Buildings 2018;165:340-51. https://doi.org/10.1016/j.enbuild.2018.01.030.

[23] Dehghan B. B. Effectiveness of using spiral ground heat exchangers in ground source heat pump system of a building for district heating/cooling purposes: Comparison among different 
configurations. Applied Thermal Engineering 2018;130:1489-506.

https://doi.org/10.1016/j.applthermaleng.2017.11.124.

[24] Li Q, Chen L, Ma H, Huang C-H. Enhanced Heat Transfer Characteristics of Graphite Concrete and Its Application in Energy Piles. Advances in Materials Science and Engineering 2018;2018:1-12. https://doi.org/10.1155/2018/8142392.

[25] Cui H, Feng T, Yang H, Bao X, Tang W, Fu J. Experimental study of carbon fiber reinforced alkaliactivated slag composites with micro-encapsulated PCM for energy storage. Construction and Building Materials 2018;161:442-51. https://doi.org/10.1016/j.conbuildmat.2017.11.075.

[26] Han C, Yu X (Bill). An innovative energy pile technology to expand the viability of geothermal bridge deck snow melting for different United States regions: Computational assisted feasibility analyses. Renewable Energy 2018;123:417-27. https://doi.org/10.1016/j.renene.2018.02.044.

[27] Huang G, Yang X, Liu Y, Zhuang C, Zhang H, Lu J. A novel truncated cone helix energy pile: Modelling and investigations of thermal performance. Energy and Buildings 2018;158:1241-56. https://doi.org/10.1016/j.enbuild.2017.11.020.

[28] Zhang W, Cui P, Liu J, Liu X. Study on heat transfer experiments and mathematical models of the energy pile of building. Energy and Buildings 2017;152:643-52.

https://doi.org/10.1016/j.enbuild.2017.07.041.

[29] Zhang W, Yang H, Lu L, Fang Z. Investigation on the heat transfer of energy piles with twodimensional groundwater flow. International Journal of Low-Carbon Technologies 2017;12:4350. https://doi.org/10.1093/ijlct/ctv028.

[30] Lu H, Jin X, Jiang G, Liu W. Numerical Analysis of the Thermal Performance of Energy Pile with UTube. Energy Procedia 2017;105:4731-7. https://doi.org/10.1016/j.egypro.2017.03.1028.

[31] Park S, Lee D, Lee S, Chauchois A, Choi H. Experimental and numerical analysis on thermal performance of large-diameter cast-in-place energy pile constructed in soft ground. Energy 2017;118:297-311. https://doi.org/10.1016/j.energy.2016.12.045.

[32] Zarrella A, Emmi G, Zecchin R, De Carli M. An appropriate use of the thermal response test for the design of energy foundation piles with U-tube circuits. Energy and Buildings 2017;134:259-70. https://doi.org/10.1016/j.enbuild.2016.10.053.

[33] Zhang H, Chen Z. Study on heat transfer performance of energy pile in GSHP system. Procedia Engineering 2017;205:2393-400. https://doi.org/10.1016/j.proeng.2017.09.861.

[34] Dehghan B, Sisman A, Aydin M. Parametric investigation of helical ground heat exchangers for heat pump applications. Energy and Buildings 2016;127:999-1007. https://doi.org/10.1016/j.enbuild.2016.06.064.

[35] Loveridge F, McCartney JS, Narsilio GA, Sanchez M. Energy geostructures: a review of analysis approaches, in situ testing and model scale experiments. Geomechanics for Energy and the Environment 2020:100173. https://doi.org/10.1016/j.gete.2019.100173.

[36] Zhang W, Yang H, Lu L, Fang Z. The analysis on solid cylindrical heat source model of foundation pile ground heat exchangers with groundwater flow. Energy 2013;55:417-25. https://doi.org/10.1016/j.energy.2013.03.092.

[37] Man Y, Yang H, Diao N, Liu J, Fang Z. A new model and analytical solutions for borehole and pile ground heat exchangers. International Journal of Heat and Mass Transfer 2010;53:2593-601. https://doi.org/10.1016/j.ijheatmasstransfer.2010.03.001.

[38] Wang D, Lin L, Aiqiang P. Investigating the Impact of Thermo-physical Property Difference between Soil and Pile on the Thermal Performance of Energy Piles. Procedia Engineering 2017;205:3199-205. https://doi.org/10.1016/j.proeng.2017.10.269.

[39] Park S, Sung C, Jung K, Sohn B, Chauchois A, Choi H. Constructability and heat exchange efficiency of large diameter cast-in-place energy piles with various configurations of heat exchange pipe. 
Applied Thermal Engineering 2015;90:1061-71.

https://doi.org/10.1016/j.applthermaleng.2015.05.044.

[40] Cui P, Li X, Man Y, Fang Z. Heat transfer analysis of pile geothermal heat exchangers with spiral coils. Applied Energy 2011;88:4113-9. https://doi.org/10.1016/j.apenergy.2011.03.045.

[41] Yuanlong Cui, Jie Zhu, Ssennoga Twaha, Saffa Riffat. A comprehensive review on 2D and 3D models of vertical ground heat exchangers. Renewable and Sustainable Energy Reviews 2018. https://doi.org/10.1016/j.rser.2018.05.063.

[42] Aresti L, Christodoulides P, Florides G. A review of the design aspects of ground heat exchangers. Renewable and Sustainable Energy Reviews 2018;92:757-73. https://doi.org/10.1016/j.rser.2018.04.053.

[43] Cui Y, Zhu J. 3D transient heat transfer numerical analysis of multiple energy piles. Energy and Buildings 2017;134:129-42. https://doi.org/10.1016/j.enbuild.2016.10.032.

[44] Bezyan B, Porkhial S, Mehrizi AA. 3-D simulation of heat transfer rate in geothermal pilefoundation heat exchangers with spiral pipe configuration. Applied Thermal Engineering 2015;87:655-68. https://doi.org/10.1016/j.applthermaleng.2015.05.051.

[45] Zarrella A, De Carli M, Galgaro A. Thermal performance of two types of energy foundation pile: Helical pipe and triple U-tube. Applied Thermal Engineering 2013;61:301-10. https://doi.org/10.1016/j.applthermaleng.2013.08.011.

[46] Carotenuto A, Marotta P, Massarotti N, Mauro A, Normino G. Energy piles for ground source heat pump applications: Comparison of heat transfer performance for different design and operating parameters. Applied Thermal Engineering 2017;124:1492-504. https://doi.org/10.1016/j.applthermaleng.2017.06.038.

[47] Caulk R, Ghazanfari E, McCartney JS. Parameterization of a calibrated geothermal energy pile model. Geomechanics for Energy and the Environment 2016;5:1-15. https://doi.org/10.1016/j.gete.2015.11.001.

[48] Laloui L, Moreni M, Vulliet L. Comportement d'un pieu bi-fonction, fondation et échangeur de chaleur. Canadian Geotechnical Journal 2003;40:388-402. https://doi.org/10.1139/t02-117.

[49] Bourne-Webb P. An overview of observed thermal and thermo-mechanical response of piled energy foundations. European Geothermal Congress. Pisa, Italy, 2013, p. 1-8.

[50] Abdelaziz S, Ozudogru TY. Non-uniform thermal strains and stresses in energy piles. Environmental Geotechnics 2016;3:237-52. https://doi.org/10.1680/jenge.15.00032.

[51] Fang P, Bouazza A, Wang Z, Xie X. Bearing Performance of Geothermal Energy Pile Subjected to Thermal Loading. In: Zhang D, Huang X, editors. Proceedings of GeoShanghai 2018 International Conference: Tunnelling and Underground Construction, Singapore: Springer Singapore; 2018, p. 710-7. https://doi.org/10.1007/978-981-13-0017-2_71.

[52] Di Donna Ai, Laloui L. Numerical analysis of the geotechnical behaviour of energy piles: NUMERICAL ANALYSIS OF THE GEOTECHNICAL BEHAVIOUR OF ENERGY PILES. International Journal for Numerical and Analytical Methods in Geomechanics 2015;39:861-88. https://doi.org/10.1002/nag.2341.

[53] Huang X, Wu Y, Peng H, Hao Y, Lu C. Thermomechanical Behavior of Energy Pile Embedded in Sandy Soil. Mathematical Problems in Engineering 2018;2018:1-11. https://doi.org/10.1155/2018/5341642.

[54] Wang D, Lu L, Cui P. Simulation of thermo-mechanical performance of pile geothermal heat exchanger (PGHE) considering temperature-depend interface behavior. Applied Thermal Engineering 2018;139:356-66. https://doi.org/10.1016/j.applthermaleng.2018.02.020.

[55] Luo J, Zhao H, Gui S, Xiang W, Rohn J. Study of thermal migration and induced mechanical effects in double U-tube energy piles. Computers and Geotechnics 2017;91:1-11. https://doi.org/10.1016/j.compgeo.2017.06.015. 
[56] Bao XH, Xiong YL, Mingi HY, Cui HZ, Liu GB, Zheng RY. Investigation on the Thermo-Mechanical Behavior of an Energy Pile and the Surrounding Soil by Model Test and 2D Finite Element-Finite Difference Method. In: Zhang D, Huang X, editors. Proceedings of GeoShanghai 2018 International Conference: Tunnelling and Underground Construction, Singapore: Springer Singapore; 2018, p. 696-709. https://doi.org/10.1007/978-981-13-0017-2_70.

[57] Bourne-Webb PJ, Bodas Freitas TM. Thermally-activated piles and pile groups under monotonic and cyclic thermal loading-A review. Renewable Energy 2018.

https://doi.org/10.1016/j.renene.2018.11.025.

[58] Kalantidou A, Tang AM, Pereira J-M, Hassen G. Preliminary study on the mechanical behaviour of heat exchanger pile in physical model. Géotechnique 2012;62:1047-51. https://doi.org/10.1680/geot.11.T.013.

[59] Yavari N, Tang AM, Pereira J-M, Hassen G. Experimental study on the mechanical behaviour of a heat exchanger pile using physical modelling. Acta Geotechnica 2014;9:385-98. https://doi.org/10.1007/s11440-014-0310-7.

[60] Soga K, Rui Y. Energy geostructures. Advances in Ground-Source Heat Pump Systems, Elsevier; 2016, p. 185-221. https://doi.org/10.1016/B978-0-08-100311-4.00007-8.

[61] Faizal M, Bouazza A, Haberfield C, McCartney JS. Axial and Radial Thermal Responses of a FieldScale Energy Pile under Monotonic and Cyclic Temperature Changes. Journal of Geotechnical and Geoenvironmental Engineering 2018;144:04018072. https://doi.org/10.1061/(ASCE)GT.19435606.0001952.

[62] Civelek S. 5.Geoteknik Sempozyumu 2017:10.

[63] Sutman M, Olgun CG, Laloui L. Cyclic Load-Transfer Approach for the Analysis of Energy Piles. Journal of Geotechnical and Geoenvironmental Engineering 2019;145:04018101. https://doi.org/10.1061/(ASCE)GT.1943-5606.0001992.

[64] Saggu R. Strain Distribution in Geothermal Energy Piles: A Parametric Study. In: Zhan L, Chen Y, Bouazza A, editors. Proceedings of the 8th International Congress on Environmental Geotechnics Volume 3, Singapore: Springer Singapore; 2019, p. 129-37. https://doi.org/10.1007/978-981-132227-3_16.

[65] Alberdi-Pagola M, Madsen S, Jensen R, Poulsen S. Numerical Investigation on the Thermomechanical Behavior of a Quadratic Cross Section Pile Heat Exchanger, International Ground Source Heat Pump Association; 2017. https://doi.org/10.22488/okstate.17.000520.

[66] Rammal D, Mroueh H, Burlon S. Impact of thermal solicitations on the design of energy piles. Renewable and Sustainable Energy Reviews 2018;92:111-20. https://doi.org/10.1016/j.rser.2018.04.049.

[67] Xiao S, Suleiman MT, Elzeiny R, Naito C, Neti S, Al-Khawaja M. Effect of Temperature and Radial Displacement Cycles on Soil-Concrete Interface Properties Using Modified Thermal Borehole Shear Test. Journal of Geotechnical and Geoenvironmental Engineering 2018;144:04018036. https://doi.org/10.1061/(ASCE)GT.1943-5606.0001892.

[68] Adinolfi M, Maiorano RMS, Mauro A, Massarotti N, Aversa S. On the influence of thermal cycles on the yearly performance of an energy pile. Geomechanics for Energy and the Environment 2018. https://doi.org/10.1016/j.gete.2018.03.004.

[69] Gawecka KA, Taborda DMG, Potts DM, Cui W, Zdravković L, Haji Kasri MS. Numerical modelling of thermo-active piles in London Clay. Proceedings of the Institution of Civil Engineers Geotechnical Engineering 2017;170:201-19. https://doi.org/10.1680/jgeen.16.00096.

[70] Rotta Loria AF, Laloui L. Group action effects caused by various operating energy piles. Géotechnique 2018;68:834-41. https://doi.org/10.1680/jgeot.17.P.213.

[71] Ouyang Y, Pelecanos L, Soga K. Finite-element modelling of thermo-mechanical soil-structure interaction in a thermo-active cement column buried in London Clay n.d.:7. 
[72] Wu D, Liu H-L, Kong G-Q, Ng CWW, Cheng X-H. Displacement response of an energy pile in saturated clay. Proceedings of the Institution of Civil Engineers - Geotechnical Engineering 2018:1-44. https://doi.org/10.1680/jgeen.17.00152.

[73] Rotta Loria AF, Vadrot A, Laloui L. Analysis of the vertical displacement of energy pile groups. Geomechanics for Energy and the Environment 2018. https://doi.org/10.1016/j.gete.2018.04.001.

[74] Nguyen VT, Tang AM, Pereira J-M. Long-term thermo-mechanical behavior of energy pile in dry sand. Acta Geotechnica 2017;12:729-37. https://doi.org/10.1007/s11440-017-0539-z.

[75] Wang C, Liu H, Kong G, Wang Wai Ng C. Different types of energy piles with heating-cooling cycles. Proceedings of the Institution of Civil Engineers - Geotechnical Engineering 2017;170:22031. https://doi.org/10.1680/jgeen.16.00061.

[76] Laloui L, Sutman M. Energy geostructures: a new era for geotechnical engineering practice. Proceedings of the XVII ECSMGE-2019 2019:5173-87. https://doi.org/10.32075/17ECSMGE-20191106.

[77] Rotta Loria AF, Laloui L. Displacement interaction among energy piles bearing on stiff soil strata. Computers and Geotechnics 2017;90:144-54. https://doi.org/10.1016/j.compgeo.2017.06.008.

[78] Jeong S, Lim H, Lee JK, Kim J. Thermally induced mechanical response of energy piles in axially loaded pile groups. Applied Thermal Engineering 2014;71:608-15.

https://doi.org/10.1016/j.applthermaleng.2014.07.007.

[79] Salciarini D, Ronchi F, Tamagnini C. Thermo-hydro-mechanical response of a large piled raft equipped with energy piles: a parametric study. Acta Geotechnica 2017;12:703-28. https://doi.org/10.1007/s11440-017-0551-3.

[80] Rotta Loria AF, Vadrot A, Laloui L. Effect of non-linear soil deformation on the interaction among energy piles. Computers and Geotechnics 2017;86:9-20. https://doi.org/10.1016/j.compgeo.2016.12.015.

[81] Loveridge F, Powrie W. 2D thermal resistance of pile heat exchangers. Geothermics 2014;50:12235. https://doi.org/10.1016/j.geothermics.2013.09.015.

[82] Mc Corry M, Jones GL. Geotrainet training manual for designers of shallow geothermal systems. Brussels: Geotrainet, EFG; 2011.

[83] Mehrizi AA, Porkhial S, Bezyan B, Lotfizadeh H. Energy pile foundation simulation for different configurations of ground source heat exchanger. International Communications in Heat and Mass Transfer 2016;70:105-14. https://doi.org/10.1016/j.icheatmasstransfer.2015.12.001.

[84] Man Y, Qu Y, Wang Z, Fang Z. Design and Analytical Analysis of Foundation Pile Ground Heat Exchanger with Spiral Coils, International Ground Source Heat Pump Association; 2017. https://doi.org/10.22488/okstate.17.000532.

[85] Zarrella A, De Carli M, Galgaro A. Thermal performance of two types of energy foundation pile: Helical pipe and triple U-tube. Applied Thermal Engineering 2013;61:301-10. https://doi.org/10.1016/j.applthermaleng.2013.08.011.

[86] Luo J, Zhao H, Gui S, Xiang W, Rohn J, Blum P. Thermo-economic analysis of four different types of ground heat exchangers in energy piles. Applied Thermal Engineering 2016;108:11-9. https://doi.org/10.1016/j.applthermaleng.2016.07.085.

[87] Jalaluddin, Miyara A. Thermal performance investigation of several types of vertical ground heat exchangers with different operation mode. Applied Thermal Engineering 2012;33-34:167-74. https://doi.org/10.1016/j.applthermaleng.2011.09.030.

[88] Lee CK, Lam HN. A simplified model of energy pile for ground-source heat pump systems. Energy 2013;55:838-45. https://doi.org/10.1016/j.energy.2013.03.077. 
[89] Zhao Q, Liu F, Liu C, Tian M, Chen B. Influence of spiral pitch on the thermal behaviors of energy piles with spiral-tube heat exchanger. Applied Thermal Engineering 2017;125:1280-90. https://doi.org/10.1016/j.applthermaleng.2017.07.099.

[90] Kavanaugh S, Rafferty K. Geothermal heating and cooling: design of ground-source heat pump systems. Atlanta: ASHRAE; 2014.

[91] GSHPA. Thermal Pile: Design, Installation \& Materials Standards 2012.

[92] Bozis D, Papakostas K, Kyriakis N. On the evaluation of design parameters effects on the heat transfer efficiency of energy piles. Energy and Buildings 2011;43:1020-9. https://doi.org/10.1016/j.enbuild.2010.12.028.

[93] Kim K-H, Jeon S-E, Kim J-K, Yang S. An experimental study on thermal conductivity of concrete. Cement and Concrete Research 2003;33:363-71. https://doi.org/10.1016/S0008-8846(02)009651.

[94] Laing D, Bahl C, Bauer T, Fiss M, Breidenbach N, Hempel M. High-Temperature Solid-Media Thermal Energy Storage for Solar Thermal Power Plants. Proceedings of the IEEE 2012;100:51624. https://doi.org/10.1109/JPROC.2011.2154290.

[95] Yang H, Memon S, Bao X, Cui H, Li D. Design and Preparation of Carbon Based Composite Phase Change Material for Energy Piles. Materials 2017;10:391. https://doi.org/10.3390/ma10040391.

[96] Guo C, Zhu J, Zhou W, Chen W. Fabrication and thermal properties of a new heat storage concrete material. Journal of Wuhan University of Technology-Mater Sci Ed 2010;25:628-30. https://doi.org/10.1007/s11595-010-0058-3.

[97] Zhao S, Chen L, Fu Y. An experimental study on mechanical properties of fiber-reinforced concrete of energy piles n.d.:1.

[98] Zhao S, Fu Y. Research on the Performance of Fiber-reinforced Energy Pile for Heat Storage n.d.:6.

[99] Brandl $\mathrm{H}$. Energy foundations and other thermo-active ground structures. Géotechnique 2006;56:81-122. https://doi.org/10.1680/geot.2006.56.2.81.

[100] Çengel YA, Cimbala JM. Fluid mechanics: fundamentals and applications. Third edition. New York: McGraw Hill; 2014.

[101] Olgun CG, McCartney JS. Outcomes from international workshop on thermoactive geotechnical systems for near-surface geothermal energy: from research to practice. DFI Journal - The Journal of the Deep Foundations Institute 2014;8:59-73. https://doi.org/10.1179/1937525514Y.0000000005.

[102] Mohamad Z, Fardoun F. Energy performance evaluation of geothermal boreholes, IEEE; 2017, p. 1-4. https://doi.org/10.1109/SENSET.2017.8125030.

[103] You S, Cheng X, Yu C, Dang Z. Effects of groundwater flow on the heat transfer performance of energy piles: Experimental and numerical analysis. Energy and Buildings 2017;155:249-59. https://doi.org/10.1016/j.enbuild.2017.09.023.

[104] Dalla Santa G, Galgaro A, Sassi R, Cultrera M, Scotton P, Mueller J, et al. An updated ground thermal properties database for GSHP applications. Geothermics 2020;85:101758. https://doi.org/10.1016/j.geothermics.2019.101758.

[105] Al Moussawi H, Fardoun F, Louahlia-Gualous H. Review of tri-generation technologies: Design evaluation, optimization, decision-making, and selection approach. Energy Conversion and Management 2016;120:157-96. https://doi.org/10.1016/j.enconman.2016.04.085.

[106] Chiasson AD. Geothermal heat pump and heat engine systems: theory and practice. New York: Asme Press; 2016.

[107] Çengel YA, Boles MA. Thermodynamics: an engineering approach. Eighth edition. New York: McGraw-Hill Education; 2015.

[108] Dinçer I, Rosen M. Exergy: energy, environment and sustainable development. 2. ed. Amsterdam: Elsevier; 2013. 
[109] Bejan A. Advanced engineering thermodynamics. 3. ed. Hoboken, NJ: Wiley; 2006.

[110] Bi Y, Wang X, Liu Y, Zhang H, Chen L. Comprehensive exergy analysis of a ground-source heat pump system for both building heating and cooling modes. Applied Energy 2009;86:2560-5. https://doi.org/10.1016/j.apenergy.2009.04.005.

[111] Menberg K, Heo Y, Choi W, Ooka R, Choudhary R, Shukuya M. Exergy analysis of a hybrid groundsource heat pump system. Applied Energy 2017;204:31-46. https://doi.org/10.1016/j.apenergy.2017.06.076.

[112] Dinçer I, Zamfirescu C. Sustainable Energy Systems and Applications. Boston, MA: Springer US; 2012. https://doi.org/10.1007/978-0-387-95861-3.

[113] Sutman M, Brettmann T, Olgun CG. Full-scale in-situ tests on energy piles: Head and baserestraining effects on the structural behaviour of three energy piles. Geomechanics for Energy and the Environment 2019;18:56-68. https://doi.org/10.1016/j.gete.2018.08.002.

[114] Rotta Loria AF, Bocco M, Garbellini C, Muttoni A, Laloui L. The role of thermal loads in the performance-based design of energy piles. Geomechanics for Energy and the Environment 2020;21:100153. https://doi.org/10.1016/j.gete.2019.100153.

[115] Kuzgunkaya EH, Hepbasli A. Exergetic performance assessment of a ground-source heat pump drying system. International Journal of Energy Research 2007;31:760-77. https://doi.org/10.1002/er.1268.

[116] Huang S, Ma Z, Wang F. A multi-objective design optimization strategy for vertical ground heat exchangers. Energy and Buildings 2015;87:233-42. https://doi.org/10.1016/j.enbuild.2014.11.024.

[117] Jeong J, Hong T, Kim J, Chae M, Ji C. Multi-criteria analysis of a self-consumption strategy for building sectors focused on ground source heat pump systems. Journal of Cleaner Production 2018;186:68-80. https://doi.org/10.1016/j.jclepro.2018.03.121.

[118] Noorollahi Y, Bigdelou P, Pourfayaz F, Yousefi H. Numerical modeling and economic analysis of a ground source heat pump for supplying energy for a greenhouse in Alborz province, Iran. Journal of Cleaner Production 2016;131:145-54. https://doi.org/10.1016/j.jclepro.2016.05.059.

[119] Morrone B, Coppola G, Raucci V. Energy and economic savings using geothermal heat pumps in different climates. Energy Conversion and Management 2014;88:189-98. https://doi.org/10.1016/j.enconman.2014.08.007.

[120] Biglarian H, Saidi MH, Abbaspour M. Economic and environmental assessment of a solar-assisted ground source heat pump system in a heating-dominated climate. International Journal of Environmental Science and Technology 2018. https://doi.org/10.1007/s13762-018-1673-3.

[121] Huang B, Mauerhofer V. Life cycle sustainability assessment of ground source heat pump in Shanghai, China. Journal of Cleaner Production 2016;119:207-14. https://doi.org/10.1016/j.jclepro.2015.08.048.

[122] Heat pumps - technology and environmental impact. HEAT PUMPS n.d.:120.

[123] GAMAGE K, YOUSEFZADEH M, UZGÖREN E, UZGÖREN YM. Optimization of a Ground Source Heat Pump System Using Monte-Carlo Simulation 2014:19.

[124] Bayer P, de Paly M, Beck M. Strategic optimization of borehole heat exchanger field for seasonal geothermal heating and cooling. Applied Energy 2014;136:445-53. https://doi.org/10.1016/j.apenergy.2014.09.029.

[125] Ma Z, Xia L. Model-based Optimization of Ground Source Heat Pump Systems. Energy Procedia 2017;111:12-20. https://doi.org/10.1016/j.egypro.2017.03.003.

[126] Robert F, Gosselin L. New methodology to design ground coupled heat pump systems based on total cost minimization. Applied Thermal Engineering 2014;62:481-91. https://doi.org/10.1016/j.applthermaleng.2013.08.003. 
[127] Li M, Lai ACK. Thermodynamic optimization of ground heat exchangers with single U-tube by entropy generation minimization method. Energy Conversion and Management 2013;65:133-9. https://doi.org/10.1016/j.enconman.2012.07.013.

[128] Huang S, Ma Z, Cooper P. Optimal design of vertical ground heat exchangers by using entropy generation minimization method and genetic algorithms. Energy Conversion and Management 2014;87:128-37. https://doi.org/10.1016/j.enconman.2014.06.094.

[129] Lu Y, Wang S, Zhao Y, Yan C. Renewable energy system optimization of low/zero energy buildings using single-objective and multi-objective optimization methods. Energy and Buildings 2015;89:61-75. https://doi.org/10.1016/j.enbuild.2014.12.032.

[130] Dinçer I, Rosen M, Ahmadi P. Optimization of energy systems. Chichester, West Sussex, UK: John Wiley \& Sons Inc; 2018.

[131] Sayyaadi H, Amlashi EH, Amidpour M. Multi-objective optimization of a vertical ground source heat pump using evolutionary algorithm. Energy Conversion and Management 2009;50:2035-46. https://doi.org/10.1016/j.enconman.2009.04.006.

[132] Park S-H, Kim J-Y, Jang Y-S, Kim E-J. Development of a Multi-Objective Sizing Method for Borehole Heat Exchangers during the Early Design Phase. Sustainability 2017;9:1876. https://doi.org/10.3390/su9101876.

[133] Evins R. A review of computational optimisation methods applied to sustainable building design. Renewable and Sustainable Energy Reviews 2013;22:230-45. https://doi.org/10.1016/j.rser.2013.02.004.

[134] Machairas V, Tsangrassoulis A, Axarli K. Algorithms for optimization of building design: A review. Renewable and Sustainable Energy Reviews 2014;31:101-12. https://doi.org/10.1016/j.rser.2013.11.036.

[135] Shaikh PH, Nor NBM, Nallagownden P, Elamvazuthi I, Ibrahim T. A review on optimized control systems for building energy and comfort management of smart sustainable buildings. Renewable and Sustainable Energy Reviews 2014;34:409-29. https://doi.org/10.1016/j.rser.2014.03.027.

[136] Sayyaadi H, Nejatolahi M. Multi-objective optimization of a cooling tower assisted vapor compression refrigeration system. International Journal of Refrigeration 2011;34:243-56. https://doi.org/10.1016/j.ijrefrig.2010.07.026.

[137] Cao K, Huang B, Wang S, Lin H. Sustainable land use optimization using Boundary-based Fast Genetic Algorithm. Computers, Environment and Urban Systems 2012;36:257-69. https://doi.org/10.1016/j.compenvurbsys.2011.08.001.

[138] Li M, Yang S, Liu X. Pareto or Non-Pareto: Bi-Criterion Evolution in Multiobjective Optimization. IEEE Transactions on Evolutionary Computation 2016;20:645-65. https://doi.org/10.1109/TEVC.2015.2504730.

[139] Sayyadi H, Nejatolahi M. Thermodynamic and thermoeconomic optimization of a cooling towerassisted ground source heat pump. Geothermics 2011. https://doi.org/10.1016/j.geothermics.2011.06.003.

[140] Sivasakthivel T, Murugesan K, Sahoo PK. Optimization of ground heat exchanger parameters of ground source heat pump system for space heating applications. Energy 2014;78:573-86. https://doi.org/10.1016/j.energy.2014.10.045.

[141] Tian W. A review of sensitivity analysis methods in building energy analysis. Renewable and Sustainable Energy Reviews 2013;20:411-9. https://doi.org/10.1016/j.rser.2012.12.014.

[142] Khalajzadeh V, Heidarinejad G, Srebric J. Parameters optimization of a vertical ground heat exchanger based on response surface methodology. Energy and Buildings 2011;43:1288-94. https://doi.org/10.1016/j.enbuild.2011.01.007. 
[143] Fernández M, Eguía P, Granada E, Febrero L. Sensitivity analysis of a vertical geothermal heat exchanger dynamic simulation: Calibration and error determination. Geothermics 2017;70:24959. https://doi.org/10.1016/j.geothermics.2017.06.012.

[144] Han C, Yu X (Bill). Sensitivity analysis of a vertical geothermal heat pump system. Applied Energy 2016;170:148-60. https://doi.org/10.1016/j.apenergy.2016.02.085.

[145] Ahmed K, Al-Khawaja M, Suleiman M. Optimization of energy pile conductance using finite element and fractional factorial design of experiment. IOP Conference Series: Materials Science and Engineering 2018;383:012034. https://doi.org/10.1088/1757-899X/383/1/012034.

[146] Cecinato F, Loveridge FA. Influences on the thermal efficiency of energy piles. Energy 2015;82:1021-33. https://doi.org/10.1016/j.energy.2015.02.001.

[147] Jelušič $P$, Žlender B. Determining optimal designs for conventional and geothermal energy piles. Renewable Energy 2020;147:2633-42. https://doi.org/10.1016/j.renene.2018.08.016.

[148] Chen S, Mao J, Chen F, Hou P, Li Y. Development of ANN model for depth prediction of vertical ground heat exchanger. International Journal of Heat and Mass Transfer 2018;117:617-26. https://doi.org/10.1016/j.ijheatmasstransfer.2017.10.006.

[149] Pandey N, Murugesan K, Thomas HR. Optimization of ground heat exchangers for space heating and cooling applications using Taguchi method and utility concept. Applied Energy 2017;190:421-38. https://doi.org/10.1016/j.apenergy.2016.12.154.

[150] Hu P, Zha J, Lei F, Zhu N, Wu T. A composite cylindrical model and its application in analysis of thermal response and performance for energy pile. Energy and Buildings 2014;84:324-32. https://doi.org/10.1016/j.enbuild.2014.07.046.

[151] Park H, Lee S-R, Yoon S, Choi J-C. Evaluation of thermal response and performance of PHC energy pile: Field experiments and numerical simulation. Applied Energy 2013;103:12-24. https://doi.org/10.1016/j.apenergy.2012.10.012.

[152] Ikeda S, Choi W, Ooka R. Optimization method for multiple heat source operation including ground source heat pump considering dynamic variation in ground temperature. Applied Energy 2017;193:466-78. https://doi.org/10.1016/j.apenergy.2017.02.047.

[153] Abdmouleh Z, Gastli A, Ben-Brahim L, Haouari M, Al-Emadi NA. Review of optimization techniques applied for the integration of distributed generation from renewable energy sources. Renewable Energy 2017;113:266-80. https://doi.org/10.1016/j.renene.2017.05.087.

[154] Afram A, Janabi-Sharifi F, Fung AS, Raahemifar K. Artificial neural network (ANN) based model predictive control (MPC) and optimization of HVAC systems: A state of the art review and case study of a residential HVAC system. Energy and Buildings 2017;141:96-113. https://doi.org/10.1016/j.enbuild.2017.02.012.

[155] Zeng R, Li H, Jiang R, Liu L, Zhang G. A novel multi-objective optimization method for CCHP-GSHP coupling systems. Energy and Buildings 2016;112:149-58. https://doi.org/10.1016/j.enbuild.2015.11.072.

[156] Sanaye S, Niroomand B. Thermal-economic modeling and optimization of vertical ground-coupled heat pump. Energy Conversion and Management 2009;50:1136-47. https://doi.org/10.1016/j.enconman.2008.11.014.

[157] Pu L, Qi D, Xu L, Li Y. Optimization on the performance of ground heat exchangers for GSHP using Kriging model based on MOGA. Applied Thermal Engineering 2017;118:480-9. https://doi.org/10.1016/j.applthermaleng.2017.02.114.

[158] Sun W, Hu P, Lei F, Zhu N, Jiang Z. Case study of performance evaluation of ground source heat pump system based on ANN and ANFIS models. Applied Thermal Engineering 2015;87:586-94. https://doi.org/10.1016/j.applthermaleng.2015.04.082. 
[159] Esen H, Inalli M. ANN and ANFIS models for performance evaluation of a vertical ground source heat pump system. Expert Systems with Applications 2010;37:8134-47.

https://doi.org/10.1016/j.eswa.2010.05.074.

[160] Gang W, Wang J. Predictive ANN models of ground heat exchanger for the control of hybrid ground source heat pump systems. Applied Energy 2013;112:1146-53. https://doi.org/10.1016/j.apenergy.2012.12.031.

[161] Retkowski W, Thöming J. Thermoeconomic optimization of vertical ground-source heat pump systems through nonlinear integer programming. Applied Energy 2014;114:492-503. https://doi.org/10.1016/j.apenergy.2013.09.012.

[162] Khan MH, Spitler JD. PERFORMANCE ANALYSIS OF A RESIDENTIAL GROUND SOURCE HEAT PUMP SYSTEM WITH ANTIFREEZE SOLUTION. SimBuild2004 2004:10.

[163] Zhang C, Hu S, Liu Y, Wang Q. Optimal design of borehole heat exchangers based on hourly load simulation. Energy 2016;116:1180-90. https://doi.org/10.1016/j.energy.2016.10.045.

[164] Verma V, Murugesan K. Optimization of solar assisted ground source heat pump system for space heating application by Taguchi method and utility concept. Energy and Buildings 2014;82:296309. https://doi.org/10.1016/j.enbuild.2014.07.029.

[165] Esen H, Turgut E. Optimization of operating parameters of a ground coupled heat pump system by Taguchi method. Energy and Buildings 2015;107:329-34.

https://doi.org/10.1016/j.enbuild.2015.08.042. 


\section{Declaration of interests}

$\bigotimes$ The authors declare that they have no known competing financial interests or personal relationships that could have appeared to influence the work reported in this paper.

$\square$ The authors declare the following financial interests/personal relationships which may be considered as potential competing interests: 